University of Wollongong

Research Online

Faculty of Engineering and Information

Faculty of Engineering and Information

Sciences - Papers: Part A

Sciences

$1-1-2016$

\title{
Axial and flexural behavior of unreinforced and FRP bar reinforced circular concrete filled FRP tube columns
}

Muhammad N. S Hadi

University of Wollongong, mhadi@uow.edu.au

Qasim Khan

University of Wollongong, qsk991@uowmail.edu.au

M Neaz Sheikh

University of Wollongong, msheikh@uow.edu.au

Follow this and additional works at: https://ro.uow.edu.au/eispapers

Part of the Engineering Commons, and the Science and Technology Studies Commons

Research Online is the open access institutional repository for the University of Wollongong. For further information contact the UOW Library: research-pubs@uow.edu.au 


\title{
Axial and flexural behavior of unreinforced and FRP bar reinforced circular concrete filled FRP tube columns
}

\begin{abstract}
Fiber Reinforced Polymer (FRP) composites have emerged as a viable alternative of steel reinforcement due to higher ultimate tensile strength to weight ratio and corrosion resistance of FRP composites. Concrete Filled Fiber Reinforced Polymer Tube (CFFT) technique for new column construction has attracted significant research attention. This paper investigated the axial and flexural behavior of concrete filled Carbon FRP (CFRP) tube columns with and without CFRP bar and concrete filled Glass FRP (GFRP) tube columns with and without GFRP bar. The test results of 16 circular CFFT and four steel Reinforced Concrete (RC) specimens of 203-205 mm diameter and 800-812 mm height have been reported in this paper. The test results showed a larger reduction in the confinement effectiveness of FRP tube than steel helices under increasing applied load eccentricity. FRP bar reinforced CFFT specimens exhibited higher axial loads, flexural loads, and deformations at peak loads than unreinforced CFFT and steel RC specimens. Experimental axial load-bending moment interaction curves of tested specimens also showed the improved performance of FRP bar reinforced CFFT specimens.
\end{abstract}

\section{Keywords}

tube, filled, concrete, circular, reinforced, bar, frp, unreinforced, behavior, columns, flexural, axial

Disciplines

Engineering | Science and Technology Studies

\section{Publication Details}

Hadi, M. N. S., Khan, Q. S. \& Sheikh, M. Neaz. (2016). Axial and flexural behavior of unreinforced and FRP bar reinforced circular concrete filled FRP tube columns. Construction and Building Materials, 122 (September), 43-53. 
2

4

\section{7}

\title{
Axial and Flexural Behavior of Unreinforced and FRP Bar Reinforced Circular Concrete Filled FRP Tube Columns
}

\author{
Muhammad N.S. Hadi ${ }^{*}$, Qasim S. Khan ${ }^{2}$, M. Neaz Sheikh ${ }^{3}$ \\ ${ }^{1 *}$ Associate Professor, School of Civil, Mining and Environmental Engineering, University of \\ Wollongong, Australia \\ ${ }^{2}$ Ph.D. Candidate, School of Civil, Mining and Environmental Engineering, University of \\ Wollongong, Australia; formerly, Assistant Professor, Civil Engineering Department, \\ University of Engineering and Technology, Lahore, Pakistan \\ ${ }^{3}$ Senior Lecturer School of Civil, Mining and Environmental Engineering, University of \\ Wollongong, Australia
}

(1)

8

\section{Correspondence:}

1 Muhammad N. S. Hadi

2 School of Civil, Mining \& Environmental Engineering

3 University of Wollongong, Australia

24 E-mail:mhadi@uow.edu.au

5 Telephone: +61242214762

26 Facsimiles: + 61242213238

\footnotetext{
* Corresponding author
} 


\title{
Axial and Flexural Behavior of Unreinforced and FRP Bar Reinforced Circular Concrete Filled FRP Tube Columns
}

\begin{abstract}
Fiber Reinforced Polymer (FRP) composites have emerged as a viable alternative of steel reinforcement due to higher ultimate tensile strength to weight ratio and corrosion resistance of FRP composites. Concrete Filled Fiber Reinforced Polymer Tube (CFFT) technique for new column construction has attracted significant research attention. This paper investigated the axial and flexural behavior of concrete filled Carbon FRP (CFRP) tube columns with and without CFRP bar and concrete filled Glass FRP (GFRP) tube columns with and without GFRP bar. The test results of 16 circular CFFT and four steel Reinforced Concrete (RC) specimens of $203-205 \mathrm{~mm}$ diameter and $800-812 \mathrm{~mm}$ height have been reported in this paper. The test results showed a larger reduction in the confinement effectiveness of FRP tube than steel helices under increasing applied load eccentricity. FRP bar reinforced CFFT specimens exhibited higher axial loads, flexural loads, and deformations at peak loads than unreinforced CFFT and steel RC specimens. Experimental axial load-bending moment interaction curves of tested specimens also showed the improved performance of FRP bar reinforced CFFT specimens.
\end{abstract}

Keywords: FRP tube, FRP bar, CFFT, Axial load, Flexural load, Ductility, $P-M$ 
- 16 CFFT and 4 steel RC specimens are tested under concentric and eccentric axial loads and flexural load.

- Failure modes and load deformation behavior of tested specimens are reported.

- Effect of eccentricity on the axial load and ductility of CFFT specimens is investigated.

- Effect of four point loads on the flexural load and ductility of CFFT is investigated.

- Experimental axial load bending moment interaction curves are presented.

64

65

66

67

68

69

70

71

72

73

74

75

76 


\section{Introduction}

The strength and ductility of steel bar Reinforced Concrete (RC) members in harsh and corrosive environments may decrease due to the corrosion of steel reinforcement. Fiber Reinforced Polymer (FRP) composites are considered as practicable alternative of steel reinforcement due to higher ultimate tensile strength to weight ratio, higher corrosion and chemical resistance, and higher electromagnetic neutrality of FRP composites [1]. Although the initial construction cost of FRP reinforcement (tubes and bars) is higher than steel reinforcement, structural members reinforced with FRP tubes and bars require less maintenance due to high corrosion resistance of FRP. Hence, the overall life cycle cost is expected to be less for structural members reinforced with FRP tubes and bars under severe environmental conditions [2].

The Concrete Filled FRP Tube (CFFT) technique for new column construction was investigated in the literature as a practicable alternative of steel RC column. In CFFT columns, FRP tube acts as longitudinal and transverse reinforcement (depending on the orientation of fibers), serves as a structural formwork and a barrier to corrosion accelerating agents. FRP tube also increases the shear strength of concrete and increases the strength and ductility of columns $[3,4]$. A number of experimental studies were conducted to investigate the axial compressive behavior of CFFT over the last two decades. It is now well understood that CFFT enhances the axial compressive strength and ductility of confined concrete due to the lateral confinement provided by the surrounding FRP tube [3, 5-12].

The flexural behavior of CFFT was also investigated as FRP tube confines the concrete in the compression side and increases the structural stiffness in both axial and circumferential directions. In addition, failure of CFFT was ductile with significant warning before the rupture of FRP tube [13-15]. The flexural behavior of CFFT depends on the 
stiffness and diameter to thickness ratio of FRP tube [16]. The CFFT exhibits higher flexural strength than steel RC beam. Moreover, fibers in the FRP tube oriented perpendicular to flexural load serve as longitudinal reinforcement and are effective in resisting load and hence increases the flexural strength [17].

In recent years, the use of FRP bar was investigated as a viable alternative of steel bar in RC members in axial compression. Numerous experimental studies were conducted to investigate the axial load-deformation behavior of FRP bar reinforced concrete columns for the effective application of FRP reinforcement in the construction industry. FRP reinforcement exhibits significantly higher corrosion resistance than steel reinforcement in RC columns. However, the axial load carrying capacity of FRP reinforced concrete columns was reported to be $5-13 \%$ smaller than the axial load capacity of steel reinforced concrete columns [1, 18-23]. Moreover, CSA-S806-12 [24] neglects the contribution of FRP bars in the compressive zone in both beams and columns, while ACI 440.1R-15 [25] does not include any recommendation for the use of longitudinal FRP bars in columns.

A number of studies reported the flexural behavior of FRP (GFRP) bar RC beams (e.g., [26-28]). The studies reported that sand coated GFPR bar RC beams exhibited higher ultimate flexural loads than steel RC beams. However, wider and deeper cracks in GFRP RC beams were observed than in steel RC beams. This was attributable to the lower modulus of elasticity of GFRP bar compared to steel bar.

A limited number of experimental studies were conducted on the behavior of bar reinforced CFFT under axial and flexure loads. Mohamed and Masmoudi [29] and Park et al. [8] tested steel bar reinforced GFRP-CFFT under concentric axial load. Axial load capacity of GFRP-CFFT was reported to be significantly increased with the addition of steel bars. Cole and Fam [30] and Mohamed and Masmoudi [31] tested GFRP bar reinforced GFRP- 
CFFT in flexure. The GFRP-CFFT exhibited lower midspan deflections, lower ductility and higher flexural loads than steel RC beams. The flexural strength of FRP bar reinforced CFFT was reported to be influenced by the modulus of elasticity and ultimate tensile strength of bar.

The majority of the research studies conducted on unreinforced and bar reinforced CFFT was focused on the behavior of columns tested under concentric axial load. However, most of the columns in actual construction are subjected to combined axial and bending moments due to load eccentricities, construction errors and lateral loads [32-34]. The experimental research studies conducted on CFFT under eccentric axial load are very limited. To the knowledge of the authors, only Lillistone and Jolly [35] tested GFRP bar reinforced CFFT under axial load at a fixed eccentricity (5\% of diameter of tube). GFRP bar reinforced CFFT columns exhibited $51 \%$ reduction in axial load carrying capacity under the eccentric axial load.

To bridge the gap in understanding the behavior of unreinforced and FRP bar reinforced CFFT columns under eccentric axial loads, experimental studies on FRP bar reinforced CFFT columns under different eccentric axial loads need to be carried out. A comprehensive research program including experimental and analytical investigations on the use of FRP reinforcement in structural members is on-going at the University of Wollongong, Australia $[23,36]$. This paper presents results of an experimental investigation on the axial and flexural behavior of concrete filled Carbon FRP (CFRP) tube columns with and without CFRP bar and concrete filled Glass FRP (GFRP) tube columns with and without GFRP bar. Analytical investigation using non-linear finite element modelling of CFFT columns is considered beyond the scope of the paper. 


\section{Experimental Program}

\subsection{Description of the Experimental Program}

Four steel Reinforced Concrete (RC) specimens, eight unreinforced Concrete Filled

FRP Tube (CFFT) specimens and eight FRP bar reinforced CFFT specimens were cast and tested at the High Bay Laboratories, School of Civil, Mining and Environmental Engineering, University of Wollongong, Australia. The specimens were divided in five groups with four specimens in each group. The first group, REF consisted of steel RC specimens. The second group, CT consisted of CFRP CFFT specimens without FRP bars. The third group, GT consisted of GFRP CFFT specimens without FRP bars. The fourth group, CTCR consisted of CFRP bar reinforced CFRP CFFT specimens. The fifth group, GTGR consisted of GFRP bar reinforced GFRP CFFT specimens. From each group, the first specimen was tested as a column under concentric axial load. The second specimen was tested as a column under 25 $\mathrm{mm}$ eccentric axial load. The third specimen was tested as a column under $50 \mathrm{~mm}$ eccentric axial load. The fourth specimen was tested as a beam under four point loading. Table 1 presents details of the specimens. The dimensions of the specimens were selected to be suitable to the capacity of the testing facilities in the laboratory. The specimens were labelled (First Column of Table 1) in two parts. The first part represents the type of FRP tube and the type of FRP bar. The second part represents load conditions (concentric and eccentric axial loads and four point loads). For example, Specimen CTCR-50 represents CFRP bar reinforced CFRP CFFT specimen tested under $50 \mathrm{~mm}$ eccentric axial load.

The REF specimens were reinforced longitudinally with six N12 (12 mm diameter deformed bars with $500 \mathrm{MPa}$ nominal tensile strength) steel bars (reinforcement ratio = $2.2 \%$ ) and helically with R10 (10 mm diameter plain bars with $250 \mathrm{MPa}$ nominal tensile 
concrete cover of $15 \mathrm{~mm}$ at the top and bottom ends and a concrete clear side cover of $20 \mathrm{~mm}$ were provided.

FRP tube properties such as thickness, ultimate tensile strength and orientation of fibers in FRP tube were selected to ensure that all tested CFFT specimens have strain hardening behavior so that FRP tubes were effective in confining the concrete. Also, the confining capacity of both types of FRP tubes is similar. CFRP and GFRP tubes of $0.5 \mathrm{~mm}$ and $1.5 \mathrm{~mm}$ thickness, respectively, were selected based on the review of literature. The modulus of elasticity of CFRP fibers was three times larger than the modulus of elasticity of GFRP fibers in the circumferential direction. FRP tubes were designed with two layers of fibers. The outer layer of fibers was orientated along the skew direction $\left( \pm 60^{\circ}\right.$ with the longitudinal direction) and inner layer of fibers orientated along the circumferential direction ( $90^{\circ}$ with the longitudinal direction). In CFRP tubes, $34 \%$ of the fibers were orientated along the circumferential direction and $66 \%$ of the fibers along skew direction. In GFRP tubes, 38\% of the fibers were orientated along the circumferential direction and $62 \%$ of the fibers along the skew direction. CFRP tubes consisted of $63 \%$ fibers and $37 \%$ resin by volume whereas GFRP tubes consisted of $60 \%$ fibers and $40 \%$ resin by volume [37]. The mechanical properties of FRP tubes are provided in Table 2.

The CTCR specimens were longitudinally reinforced with six $15 \mathrm{~mm}$ nominal diameter CFRP bars (reinforcement ratio $=3.3 \%$ ). The GTGR specimens were longitudinally reinforced with six $15.9 \mathrm{~mm}$ nominal diameter GFRP bars (reinforcement ratio $=3.7 \%$ ). CFRP and GFRP bars were pultruded bars with all the fibers orientated along the longitudinal direction. The difference in longitudinal reinforcement ratios of Specimens REF, CTCR and GTGR was to incorporate the differences in modulus of elasticity and surface conditions of bars. CFRP bars consisted of $55-60 \%$ fibers and $40-45 \%$ resin by volume [37]. GFRP bars 
consisted of $73 \%$ fibers and $27 \%$ resin by volume [38]. GFRP bars were sand coated whereas

CFRP bars were smooth without any coating. In CTCR and GTGR specimens, a concrete cover of $15 \mathrm{~mm}$ at the top and bottom ends was provided.

\subsection{Specimen Preparation}

PVC pipes and FRP tubes were used as formworks for the test specimens. For REF specimens, PVC pipes of $205 \mathrm{~mm}$ inner diameter and $800 \mathrm{~mm}$ height were cleaned and placed in a wooden frame. Sixteen FRP tubes of $203 \mathrm{~mm}$ inner diameter and $812 \mathrm{~mm}$ height were cleaned and placed in a separate wooden frame. The wooden frames were made of plywood and consisted of circular holes of $207 \mathrm{~mm}$ inner diameter. In REF specimens, steel reinforcement cage was placed in PVC formworks on top of plastic chairs to provide the required concrete cover at the ends of the specimen. In CTCR and GTGR specimens, FRP bars were glued on the inner side of the tube along the circumference (60 degrees apart).

The specimens were cast with a batch of ready mix concrete obtained from a local supplier. The measured slump of the concrete batch was $120 \mathrm{~mm}$. The maximum aggregate size of the ready mix concrete was $10 \mathrm{~mm}$. The concrete was poured into the formworks in three stages. In every stage concrete was compacted using an electrical vibrator to remove air pockets within the concrete. After casting, all the specimens were cured by covering them with wet hessian rugs and plastic sheets to retain moisture for 28 days. The REF specimens were removed from the PVC pipes after 7 days. After curing, the top and bottom ends of the specimens to be tested under eccentric axial loads were vertically wrapped with $0.5 \mathrm{~mm}$ thick CFRP sheet up to $100 \mathrm{~mm}$. Afterwards, the top and bottom ends of all the specimens were wrapped with two layers of $0.5 \mathrm{~mm}$ thick and $35 \mathrm{~mm}$ wide CFRP sheet in the circumferential direction. The FRP wrapping at the specimen ends was done to prevent premature failure during testing. 


\subsection{Preliminary Material Testing}

Preliminary material testing included testing concrete cylinders, steel bars and FRP bars. The concrete cylinders of $100 \mathrm{~mm}$ diameter and $200 \mathrm{~mm}$ height were cast as recommended in AS1012.9-1999 [39] and cured in a water tank. The concrete cylinders were tested at 7 and 28 days. The average compressive cylinder strengths at 7 and 28 days were 30.9 $\mathrm{MPa}$ and $37 \mathrm{MPa}$, respectively. Five specimens each of $400 \mathrm{~mm}$ in length from each of $\mathrm{N} 12$ and R10 steel bars were tested in tension using the $500 \mathrm{kN}$ Instron testing machine according to AS1391-2007 [40]. The average tensile strengths of N12 and R10 bars were 600 $\mathrm{MPa}$ and $400 \mathrm{MPa}$, respectively. The cross-sectional area of CFRP and GFRP bars were measured by immersion test as recommended in ISO 104061-1 [41]. The average crosssectional area and diameter of CFRP bar were $177 \mathrm{~mm}^{2}$ and $15 \mathrm{~mm}$, respectively, which were identical to nominal cross-sectional area and diameter provided by the manufacturer [37]. The average cross-sectional area and diameter of GFRP bar were $292 \mathrm{~mm}^{2}$ and $19.3 \mathrm{~mm}$, respectively. The nominal cross-sectional area and diameter of GFRP bar provided by the manufacturer were $198 \mathrm{~mm}^{2}$ and $15.9 \mathrm{~mm}$, respectively [38]. The difference in the nominal and measured cross-sectional area and diameter of GFRP bar might be due to sand coat. Although, sand coat improves the bond between bar and concrete, its effect on the strength of bar is negligible. Hence the nominal cross-sectional area and diameter of CFRP and GFRP bars were used in calculating the ultimate strength and modulus of elasticity. Three specimens of $1555 \mathrm{~mm}$ in length from each of the $15 \mathrm{~mm}$ diameter CFRP bars and $15.9 \mathrm{~mm}$ diameter GFRP bars were tested in tension using the $500 \mathrm{kN}$ Instron testing machine according to ASTM D7205/D7205M-11 [42]. The average tensile strengths of CFRP and GFRP bars were $1157 \mathrm{MPa}$ and $1395 \mathrm{MPa}$, respectively. The average tensile modulus of elasticity of CFRP and GFRP bars was $89.4 \mathrm{GPa}$ and $56 \mathrm{GPa}$, respectively. Five specimens from each of $15 \mathrm{~mm}$ diameter CFRP bars (60 $\mathrm{mm}$ in length) and $15.9 \mathrm{~mm}$ diameter GFRP 
bars $(80 \mathrm{~mm}$ in length) were tested in compression using the $100 \mathrm{kN}$ Instron testing machine according to ASTM D695-10 [43]. The average compressive strength of CFRP and GFRP bars was $596 \mathrm{MPa}$ and $846 \mathrm{MPa}$, respectively. The average compressive modulus of elasticity of CFRP and GFRP bars was $49 \mathrm{GPa}$ and $42 \mathrm{GPa}$, respectively.

\section{Test Procedures and Instrumentation}

251

252

\subsection{Specimens under concentric and eccentric axial loads}

The top end of the column specimens to be tested under concentric axial load were capped with high strength plaster within a circular loading head of $235 \mathrm{~mm}$ inner diameter and $100 \mathrm{~mm}$ height made from high strength steel (Fig. 1a). The loading head was centered over the top end of the specimens to remove minor eccentricities. The top and bottom ends of the specimens to be tested under eccentric axial loads were capped with high strength plaster within the circle inscribed in square loading heads. The loading heads consisted of a $235 \mathrm{~mm}$ square cross section adaptor plate of $50 \mathrm{~mm}$ thickness (Fig. 1b) and ball joint plate of $50 \mathrm{~mm}$ thickness (Fig. 1c). The adaptor plate has two sockets along the length of the plate for the application of $25 \mathrm{~mm}$ and $50 \mathrm{~mm}$ eccentric axial loads. The loading heads were first centered over the capped top and bottom ends of the specimens and then the ball joint plates were firmly placed in the required sockets. To measure the axial deformation of the test specimens, two vertical LVDTs were fixed along the two opposite corners of the $5000 \mathrm{kN}$ Denison Universal Testing Machine (UTM) in the test region. For the specimens tested under eccentric axial load, a laser triangulation was placed at the mid-height of the specimens to measure the lateral deformations $(\delta)$ of the specimens. The specimens were tested in the UTM as shown in Fig. 2(a) and 2(b). The specimens were preloaded to $100 \mathrm{kN}$ under a force controlled load application at the rate of $50 \mathrm{kN} / \mathrm{min}$ to adjust minor misalignments between the specimen and the UTM loading heads then unloaded to $20 \mathrm{kN}$. Afterwards, the testing 
was resumed under a displacement controlled load application at the rate of $0.3 \mathrm{~mm} / \mathrm{min}$ until the rupture of FRP tube or the resistance of the specimens dropped to $25 \%$ of the peak load.

\subsection{Testing of specimens under four point loads}

The beam specimens were tested under four point loading using two platen rigs (top and bottom) placed diagonally in the UTM (Fig. 1d). To test the specimens, the bottom platen rig of clear span of $705 \mathrm{~mm}$ was placed diagonally across the centerline on the bottom loading head of the UTM. A laser triangulation was attached to the bottom platen rig to measure midspan deflections. Specimens were centered over the bottom platen rig with 53.5 $\mathrm{mm}$ overhang at the ends. The clear span of the bottom platen rig was marked on the specimen and divided in three equal segments of $235 \mathrm{~mm}$ lengths (Fig. 2c). The top platen rig was centered over the top of the middle segment of the specimen. To measure midspan deflection, two vertical LVDTs were fixed on the two opposite corners of the UTM in the test region. The specimens were preloaded to $100 \mathrm{kN}$ under a force controlled load application at the rate of $50 \mathrm{kN} / \mathrm{min}$ then unloaded to $20 \mathrm{kN}$. Afterwards, the test was resumed under a displacement controlled load application at the rate of $0.3 \mathrm{~mm} / \mathrm{min}$ until the resistance of the specimens dropped to $25 \%$ of the peak load or midspan deflection reached to $45 \mathrm{~mm}$.

\section{Experimental Results and Discussions}

The ductility $(\mu)$ of the tested specimens was calculated using the energy method in which ductility is considered as the ratio of areas under the axial load-axial deformation curve [44]. The ductility of the tested specimens was calculated according to Equation 1.

$$
\mu=\frac{A_{2}}{A_{1}}
$$


where $A_{1}$ and $A_{2}=$ area under load deformation curve up to $\delta_{y}$ and $\delta_{u}$, respectively [34, 45 - 47]

291

292

293

294

295

296

297

[45-47]. To compute $\delta_{y}$, a best fit regression line to the initial linear elastic part of the load deformation curve and a horizontal line corresponding to the peak load of the specimen were drawn. The deformation corresponding to intersection of the extrapolated best fit regression line and the horizontal line represent the yield deformation $\delta_{y}$. The deformation corresponding to $85 \%$ of the peak load in the descending part of the load-deformation curve represents $\delta_{u}$ (Fig. 3).

All specimens were tested to the rupture of CFFT. The failure of specimens tested under concentric axial load was marked by rupturing of fibers at the mid-height of the specimen and crushing of concrete. Unreinforced CFFT specimens tested under eccentric axial load were split in two halves at the mid-height of the specimen with crushing of concrete. FRP bar reinforced CFFT specimens tested under eccentric axial load failed by rupturing of fibers close to the mid-height of the specimen with outward buckling of FRP bars and crushing of concrete. Unreinforced CFFT specimens tested under four point loads failed by rupturing of fibers and splitting of concrete in two halves in the middle third segment whereas FRP bar reinforced CFFT specimens failed by rupturing of fibers with bending of bars and crushing of concrete.

\subsection{Concrete filled FRP tube specimens under concentric axial load}

Specimens CT-0 and GT-0 failed in a brittle manner with loud snapping sounds from rupturing of fibers followed by crushing of concrete. Specimen CTCR-0 failed with very loud snapping sounds from rupturing of fibers along the entire height of the specimen and crushing of concrete. In Specimen CTCR-0, outward buckling of CFRP bars was observed which indicated that CFRP bars were effective in carrying axial load. Specimen GTGR-0 failed in 
the top one-third segment of the specimen with rupturing of the top end of the GFRP bars. At failure, the peak axial load in Specimen GTGR-0 did not drop to zero unlike Specimen CTCR-0. The axial load in Specimen GTGR-0 dropped to $25 \%$ of the peak axial load without further reduction in axial load with increasing axial deformation until the test was stopped. The failure of Specimen REF-0 was characterized by spalling of the concrete cover, crushing of concrete and buckling of steel bars without rupturing of steel helix (Fig. 4).

The axial load-deformation behaviors of the tested column specimens under concentric axial load are presented in Fig. 5. Specimens CT-0, GT-0, CTCR-0 and GTGR-0 carried $15.8 \%, 23.2 \%, 43.7 \%$ and $83.9 \%$ higher peak axial loads, respectively, than the axial load carried by Specimen REF-0. Specimens CT-0, GT-0, CTCR-0 and GTGR-0 showed $73.1 \%, 117.9 \%, 52.2 \%$ and $88.1 \%$ higher ductility, respectively, than Specimen REF-0. The higher peak axial loads and ductility in Specimens CT-0 and GT-0 than the peak axial load and ductility in Specimen REF-0 indicate the greater effectiveness of FRP tube in confining the concrete than steel helix. The effect of FRP tube confinement was more pronounced in increasing the ductility than peak axial loads. This is because FRP tubes have two-thirds of the fibers orientated along the circumferential direction which were effective in confining concrete. Specimens CTCR-0 carried 24.1\% higher peak axial load than Specimen CT-0. Similarly, Specimen GTGR-0 carried 49.3\% higher peak axial load than Specimen GT-0. This showed that FRP bars were also effective in resisting axial compression along with concrete (Table 3).

\subsection{Concrete filled FRP tube specimens under eccentric axial load}

Specimens CT-25 and GT-25 failed by splitting in two halves at the mid-height accompanied by the rupture of fibers and crushing of concrete. The failure in Specimens CTCR-25 and GTGR-25 was characterized by rupture of fibers, outward buckling of FRP 

and GTGR-25 did not split into two halves at the mid-height of the specimens because of the presence of FRP bars. In Specimen CTCR-25, most of the fibers ruptured near the mid-height whereas in Specimen GTGR-25, most of the fibers ruptured near the top one-third segment of the specimen. The failure of Specimen REF-25 was due to the crushing of concrete without buckling of steel bars and fracture of steel helix (Fig. 6).

The axial load-axial deformation behaviors of tested column specimens under $25 \mathrm{~mm}$ eccentric axial load are shown in Fig. 7. Specimens CT-25 and GT-25 carried $15.0 \%$ and 3.2\% smaller peak axial loads, respectively, than Specimen REF-25. This might be due to the reduction in the confinement effectiveness of FRP tubes under eccentric axial load as tubes were subjected to both axial compression and bending moment. Also, Specimens CT-25 and of fibers mainly in the top one-third segment of the specimen along with crushing of concrete

The failure of Specimens CT-50 and GT-50 was characterized by splitting of the specimens in two halves at the mid-height with crushing of concrete and rupture of fibers. Specimen CTCR-50 failed due to rupture of fibers at the mid-height with significant lateral deformation but without splitting of the specimen. Specimen GTGR-50 failed due to rupture but without splitting of specimen in two halves. Specimen REF-50 failed due to crushing of 
concrete primarily in the top half of the specimens without buckling of steel bars or rupturing of steel helix (Fig. 8).

The axial load-deformation behaviors of the tested column specimens under $50 \mathrm{~mm}$ eccentric axial load are presented in Fig. 9. Specimens CT-50 and GT-50 carried 17.7\% and 11.2\% smaller peak axial loads, respectively, than Specimen REF-50. Specimen CTCR-50 and GTGR-50 carried $12.1 \%$ and 53.2\% larger peak axial load than Specimen REF-50. Specimen CT-50 exhibited 1.9\% smaller ductility than Specimen REF-50 whereas Specimen GT-50 exhibited 15.4\% larger ductility than Specimen REF-50. This shows that the confinement effectiveness of FRP tube was reduced under $50 \mathrm{~mm}$ eccentric axial load. However, Specimens CTCR-50 and GTGR-50 exhibited 72.7\% and 107.8\% larger ductility, respectively, than Specimen REF-50 (Table 3).

\subsection{Effect of Eccentricity}

The effect of eccentricity on peak axial loads and ductility of the 15 specimens tested as columns is presented in Fig. 10. Increase in eccentricity resulted in larger reduction in peak axial loads in CFFT specimens (CT, GT, CT-CR and GT-GR) than in steel RC specimens (REF). This may be because the modulus of elasticity of FRPs is smaller than the modulus of elasticity of steel. Moreover, FRPs have smaller compressive strength than tensile strength. In general, increased eccentricity resulted in larger reduction in peak axial load in unreinforced CFFT (CT and GT) specimens than in FRP bar reinforced CFFT (CTCR and GTGR) specimens. Increase in eccentricity resulted in decrease in ductility of tested specimens. The CT and GT specimens exhibited significantly larger reduction in ductility than CTCR and GTGR specimens. The smaller reduction in ductility of CTCR and GTGR specimens is due to the addition of FRP bars which were effective in carrying axial compressive loads. The reduction in ductility in REF specimens was smaller than the reduction in ductility in CT and 
GT specimens, although FRP tubes have two-thirds of the fibers orientated along the circumferential direction but FRPs are significantly weaker in compression than in tension.

387

Increase in eccentricity resulted in larger reduction in ductility in GFRP-CFFT specimens than in CFRP-CFFT specimens as modulus of elasticity of GFRP tube was one-third of modulus of elasticity of CFRP tube.

\subsection{Concrete filled FRP tube specimens under four point loads}

Specimen CT-B failed due to rupture of inner circumferential fibers and outer skew fibers and also split in two halves in the middle segment of the specimen. The failure in Specimen GT-B was due to the rupture of inner circumferential fibers. However, the outer skew fibers were stretched but did not rupture. The specimen was split in two halves in the middle-third segment. Moreover, no slippage between FRP tube and concrete was observed. The observed failure in Specimens CTCR-B and GTGR-B was characterized by rupturing of fibers and bending of bars without splitting of the specimen. Specimens CTCR-B and GTGRB failed due to rupture of fibers on the bottom (tension) and top (compression) sides with bending of bars and crushing of concrete. Slippage of CFRP bars in Specimen CTCR-B was observed whereas slippage of GFRP bars in Specimen GTGR-B was very small. CFRP bars were slipped as CFRP bars were smooth uncoated bars. Specimen REF-B failed with wide and long flexural cracks in the tension region followed by crushing of concrete in the compression region within the middle segment of the tested specimen (Fig. 11).

Flexural load versus midspan deflections of beam specimens tested under four point loads is shown in Fig. 12. Specimens CT-B and GT-B carried $73.2 \%$ and $66.6 \%$ smaller peak flexural loads, respectively, and $28.4 \%$ and $27.4 \%$ smaller midspan deflections at peak flexural load, respectively, than Specimen REF-B. This may be due to the fact that most of the fibers in both CFRP and GFRP tubes were orientated along the circumferential direction 
and were not very effective in resisting flexural load under bending. Specimen CTCR-B

410

411

412

413

414

415

416

417

418

419

420

421

422

423

424

425

426

427

428

429

430 carried $35.7 \%$ smaller flexural load and $24.4 \%$ smaller midspan deflection at peak flexural load than Specimen REF-B, as smooth CFRP bars slipped under the applied four point loads due to smaller friction between the bars and the concrete. Specimen GTGR-B carried $29.3 \%$ larger flexural load and $22.0 \%$ smaller midspan deflection at peak flexural load than Specimen REF-B, although GFRP bars were sand coated and exhibited higher frictional resistance between the bars and the concrete but small slippage was still observed. The measured results of Specimen GTGR-B obtained in this study were close to the test results reported by Cole and Fam [30] and Masmoudi and Mohamed [31]. Specimens CTCR-B and GTGR-B exhibited larger midspan deflections at ultimate flexural load than Specimen REFB. Specimens CT-B, GT-B, CTCR-B and GTGR-B exhibited 63.7\%, 50.4\%, $12.0 \%$ and $1.0 \%$, respectively, smaller ductility than REF-B (Table 4).

\section{Experimental Axial Load Bending Moment Interaction Diagrams}

The experimental axial load-bending moment interaction diagrams for CT, GT, CTCR, GTGR and REF specimens were drawn using pure axial load ( $e=0 \mathrm{~mm}$ ), combined axial and bending ( $e=25 \mathrm{~mm}$ and $e=50 \mathrm{~mm}$ ) and bending (four point load) to investigate the axial load bending moment capacity of the tested specimens. The bending moment capacity $(M)$ of the column specimens was calculated considering both the primary and secondary moments. The primary moment $\left(M_{I}\right)$ was due to applied load eccentricity $(e)$ while the secondary moment $\left(M_{I I}\right)$ was due to lateral deformations $(\delta)$ corresponding to the peak applied load. The bending moment capacity $(M)$ of the specimens tested as columns was calculated using Equation (1):

$$
M=M_{I}+M_{I I}=P e+P \delta
$$


where $P$ is the applied axial load. The bending moment capacity $(M)$ of specimens tested as beams under four point loads was calculated using Equation (2):

$$
M=\frac{P L}{6}
$$

where $P$ is the applied flexural load under four point loads arrangement and $L$ is the span length of test specimen. In this study the span length was $705 \mathrm{~mm}$ (Table 5).

In constructing the axial load-bending moment interaction $(P-M)$ curves for $\mathrm{CT}$, GT, CTCR and GTGR specimens, peak loads and lateral deformations at peak loads were selected under different load conditions. This approach of constructing axial load-bending moment interaction diagram for FRPs is similar to the axial load-bending moment interaction diagram approach adopted by Yazici and Hadi [48], Hadi and Zhao [49], Hadi and Widiarsa [45] and Hadi et al. [46] for different types of FRP confinements for RC members. The peak load corresponds to the maximum value of load resisted by the specimen before the rupture of FRP tube. The peak load in REF specimens was assumed to be the load at the first peak of axial load-axial deformation curve (cover spalling) of steel RC specimens.

The plotted axial load-bending moment interaction $(P-M)$ curves showed that FRP bar reinforced CFFT specimens (CTCR and GTGR) exhibited higher peak loads and bending moments than unreinforced CFFT specimens (CT and GT) (Fig. 13) which could be attributed to the increase in load carrying capacity of specimens due to the addition of FRP bars. The GT and GTGR specimens exhibited higher peak loads and bending moments than the CT and CTCR specimens. The peak loads and bending moments of GTGR specimens were higher than those of CTCR specimens. This was due to the fact that GFRP bars have higher compressive and tensile strengths than CFRP bars. Moreover, sand coated GFRP bars have higher frictional resistance and better compatibility with concrete than the frictional resistance and compatibility between smooth CFRP bars. The axial load-bending moment 
interaction curve for REF specimens was similar to the axial load-bending moment interaction curves for CT and GT specimens. This shows that unreinforced CFFTs were both effective in resisting load and confining the concrete under different load conditions. The axial load-bending moment interaction curves for CTCR and GTGR specimens were significantly larger than the axial load-bending moment interaction curve for REF specimens exhibiting the effectiveness of FRP bars in resisting loads in addition to CFFT.

\section{Conclusions}

In this experimental study, 16 concrete filled FRP tube (CFFT) specimens (CT, GT, CTCR and GTGR) were tested to investigate the influence of FRP tube confinement and FRP bars on the load-deformation behavior under different load conditions. Four conventional steel Reinforced Concrete (RC) specimens (REF) were also tested for comparison purposes. Based on the experimental results of this study, the following conclusions are drawn:

1. Unreinforced CFFT (CT and GT) specimens resisted higher axial loads and axial deformation at peak loads than REF specimens under concentric axial loads. CT and GT specimens resisted smaller axial loads than REF specimens under axial eccentric loads. The average axial and lateral deformations at peak loads in CT and GT specimens were higher than those in REF specimens under eccentric axial loads. Unreinforced CFFT (CT-B and GT-B) specimens resisted smaller flexural loads and midspan deflections than Specimen REF-B.

2. The CFFT specimens exhibited larger decrease in peak axial load than REF specimens with an increase in the applied load eccentricity from $0 \mathrm{~mm}$ to $50 \mathrm{~mm}$. The CFFT specimens exhibited higher average ductility than REF specimens under applied load eccentricity of $0 \mathrm{~mm}, 25 \mathrm{~mm}$ and $50 \mathrm{~mm}$. Reduction in ductility in REF specimens was smaller than the reduction in ductility of CT and GT specimens, 
however, reduction in ductility of REF specimens was larger than the reduction in ductility in CTCR and GTGR specimens as the applied load eccentricity was increased from 0 to $50 \mathrm{~mm}$.

3. FRP bar reinforced CFFT (CTCR and GTGR) specimens exhibited higher average axial loads and higher axial and lateral deformations at peak loads than REF specimens tested under concentric and eccentric axial loads.

4. FRP bar reinforced CFFT (CTCR-B and GTGR-B) specimens exhibited higher ultimate midspan deflections than Specimen REF-B. Specimen GTGR-B resisted higher flexural load than Specimen REF-B. Specimen CTCR-B resisted smaller flexural load than Specimen REF-B due to slippage of CFRP bars.

5. The axial load-bending moment capacity of GTGR and CTCR specimens were larger than the axial load-bending moment capacity of CT, GT, and REF specimens. The axial load-bending moment capacity of GT and CT specimens was similar to the axial load-bending moment capacity of REF specimens.

The use of FRP tube confined concrete can be recommended in combination with FRP bars to enhance the peak axial load and ductility of columns under eccentric axial compression as an alternative of steel RC columns in areas where corrosion of steel bar is a major concern.

\section{Acknowledgements}

The authors thank the University of Wollongong, Australia for providing the funding and facilities to carry out the experimental work presented in this study. The authors also acknowledge the technical assistance provided by Senior Technical Officer Messrs. Fernando Escribano, Ritchie Mclean and Alan Grant. The second author thanks the University of 
500 Engineering and Technology, Lahore, Pakistan and the University of Wollongong, Australia 501 for funding his $\mathrm{PhD}$ studies.

502

503

504

505

506

507

508

509

510

511

512

513

514

515

516

517

518

519

520

521

522

523

524

525

526 


\section{References}

528 [1] Pantelides C, Gibbons M, Reaveley L. Axial load behavior of concrete columns confined with GFRP spirals. Journal of Composites for Construction 2013;17(3):305313.

[2] Tobbi H, Farghaly AS, Benmokrane B. Behavior of concentrically loaded FiberReinforced Polymer reinforced concrete columns with varying reinforcement types and ratios. ACI Structural Journal 2014;111(2):375-385.

[3] Mirmiran A, Shahawy M. Behaviour of concrete columns confined by fiber composites. Journal of Structural Engineering 1997;123(5):583-590.

[4] Lillistone D, Jolly CK. An innovative form of reinforcement for concrete columns using advanced composites. The Structural Engineer 2000;78(23/24):20-29.

[5] Saafi M, Toutanji HA, Li Z. Behaviour of concrete columns confined with fiber reinforced polymer tubes. ACI Materials Journal 1999;96(4):500-509.

[6] Fam AZ, Rizkalla SH. Behaviour of axially loaded concrete filled circular fiber reinforced polymer tubes. ACI Structural Journal 2001;98(3):280-289.

[7] Hong WK, Kim HC. Behaviour of concrete columns confined by carbon composites tubes. Canadian Journal of Civil Engineering 2004;31(2):178-188.

[8] Ozbakkaloglu T, Oehlers DJ. Concrete filled square and rectangular FRP Tubes under axial compression. Journal of Composites for Construction 2008;12(4):469-477.

[9] Park JH, Jo BW, Yoon SJ, Park SK. Experimental investigation on the structural behaviour of concrete filled FRP tubes with/without steel rebar. KSCE Journal of Civil Engineering 2011;15(2):337-345.

[10]. Ozbakkaloglu T, Vincent T. Axial compressive behaviour of circular high strength concrete filled FRP tubes. Journal of Composites for Construction 2013; 17(1):151161.

[11] Vincent T, Ozbakkaloglu T. Influence of concrete strength and confinement method on axial compressive behaviour of FRP confined high and ultra high strength concrete. Composites Part B: Engineering 2013;50:413-428.

[12] Hadi MNS, Wang W, Sheikh MN. Axial compressive behaviour of GFRP tube reinforced concrete columns. Construction and Building Materials 2015;81:198-207.

[13] Mirmiran A, Shahawy M, Samaan M. Strength and ductility of hybrid FRP-Concrete Beam-Columns. Journal of Structural Engineering 1998;125(10):1085-1093.

[14] Mirmiran A, Shahawy M, El Khoury C, Naguib W. Large beam column tests on concrete filled composite tubes. ACI Structural Journal 2000;97(2):268-276.

[15] Davol A, Burgueño R, Seible F. Flexural behavior of circular concrete filled FRP shells. Journal of Structural Engineering 2001;127(7):810-817.

[16] Fam A, Rizkalla S. Flexural behavior of concrete filled Fiber-Reinforced Polymer circular tubes. Journal of Composites for Construction 2002;6(2):123-132.

[17] Fam A, Cole B, Mandal S. Composite tubes as an alternative to steel spirals for concrete members in bending and shear. Construction and Building Materials 2007;21(2):347-355.

[18] Alsayed SH, Al-Salloum YA, Almusallam TH, Amjad MA. Concrete columns reinforced by GFRP Rods. In: Proceedings of the $4^{\text {th }}$ International Symposium on Non-Metallic (FRP) Reinforcement for Concrete Structures; 1999.

[19] De Luca A, Matta F, Nanni A. Behaviour of full scale Glass Fiber Reinforced Polymer reinforced concrete columns under axial load. ACI Structural Journal 2010;107(5):589-596. 
[20] Tobbi H, Farghaly AS, Benmokrane B. Concrete columns reinforced longitudinally and transversally with Glass Fiber-Reinforced Polymer bars. ACI Structural Journal 2012;109(4):551-558.

[21] Afifi M, Mohamed H, Benmokrane B. Axial capacity of circular concrete columns reinforced with GFRP bars and spirals. Journal of Composites for Construction 2014;18(1):04013017-1-11.

[22] Afifi M, Mohamed H, Benmokrane B. Strength and axial behavior of circular concrete columns reinforced with CFRP bars and spirals. Journal of Composites for Construction 2014;18(2):04013035-1-10.

[23] Hadi MNS, Karim H, Sheikh MN. Experimental investigations on circular concrete columns reinforced with GFRP bars and helices under different loading conditions. Journal of Composites for Construction 2016; (DOI: Permalink: http://dx.doi.org/10.1061/(ASCE)CC.1943-5614.0000670).

[24] CSA S806-12. Design and construction of building components with fiber reinforced polymers. Ontario, Canada;Canadian Standards Association; 2012.

[25] ACI 440.1R-15. Guide for the design and construction of structural concrete reinforced with FRP Bars. United States;American Concrete Institute;2015.

[26] Faza SS, Gangarao HVS. Pre and post-cracking deflection behaviour of concrete beams reinforced with fibre-reinforced plastic rebars. In: Proceedings of Advanced Composite Materials in Bridges and Structures 1992;151 - 160.

[27] Nanni A. Flexural behavior and design of RC members using FRP reinforcement. Journal of Structural Engineering 1993;119(11):3344-3359.

[28] Benmokrane B, Chaallal O, Masmoudi R. Glass Fibre Reinforced Plastic (GFRP) rebars for concrete structures. Construction and Building Materials 1995;9(6):353364.

[29] Mohamed H, Masmoudi R. Axial load capacity of concrete filled FRP tube columns: Experimental versus theoretical predictions. Journal of Composites for Construction 2010;14(2):231-243.

[30] Cole B, Fam A. Flexural load testing of concrete filled FRP tubes with longitudinal steel and FRP rebar. Journal of Composites for Construction 2006;10(2):161-171.

[31] Mohamed HM, Masmoudi R. Flexural strength and behavior of steel and FRPreinforced concrete filled FRP tube beams. Engineering Structures 2010;32(11):37893800.

[32] Hadi MNS. Behaviour of FRP wrapped normal strength concrete columns under eccentric loading. Composite Structures 2006;72(4):503-511.

[33] Hadi MNS. Behaviour of FRP strengthened concrete columns under eccentric compression loading. Composite Structures 2007;77:92-96.

[34] Hadi MNS. Behaviour of eccentric loading of FRP confined fibre steel reinforced concrete columns. Construction and Building Materials 2009;23(2):1102-1108.

[35] Lillistone D, Jolly CK. Concrete filled fibre reinforced plastic circular columns. In; Proceedings of Composite construction-conventional and innovative conference, composite construction-Conventional and innovative; 1997:759-764.

[36] Wang W, Sheikh MN, Hadi MNS. Behaviour of perforated GFRP tubes under axial compression. Thin-Walled Structures 2015;95:88-100.

[37] CST. CST Composites, Caringbah NSW 1495, Australia, $2016 .<$ http://www.cstcomposites.com/products-and-services/tubes-rods-and-components/> (Accessed on January 20, 2016). 
[38] V-Rod. Composite reinforcing rods technical data sheet. Largs Bay SA, Australia, 2012.

[39] AS1012.9-1999. Methods of testing concrete, Method 9: Determination of the compressive strength of concrete specimens. Sydney, NSW; Australian Standard;1999.

[40] AS1391-2007 . Metallic materials - Tensile testing at ambient temperature. Sydney, NSW; Australian Standard;2007.

[41] ISO 10406-1. Fibre reinforced polymer (FRP) reinforcement of concrete - Test methods - Part 1: FRP bars and grids. Switzerland; International Standard;2015.

[42] ASTM D7205/D7205M-11. Standard Test Method for Tensile Properties of Fiber Reinforced Polymer Matrix Composite Bars. 100 Barr Harbor Drive, PO Box C700, West Conshohocken, PA 19428-2959, United States; American Society for Testing and Materials; 2011.

[43] ASTM D695-10. Standard Test Method for Compressive Properties of Rigid Plastics. 100 Barr Harbor Drive, PO Box C700, West Conshohocken, PA 19428-2959, United States; American Society for Testing and Materials; 2010.

[44] Foster J, Attard MM. Experimental tests on eccentrically loaded high strength concrete columns. ACI Structure Journal 1997;94(3):295-303.

[45] Hadi M, Widiarsa I. Axial and flexural performance of square RC columns wrapped with CFRP under eccentric loading. Journal of Composites for Construction 2012;16(6):640-649.

[46] Hadi MNS, Pham T, Lei X. New method of strengthening reinforced concrete square columns by circularizing and wrapping with Fiber-Reinforced Polymer or steel straps. Journal of Composites for Construction 2013;17(2):229-238.

[47] Saljoughian A, Mostofinejad D. Corner strip-batten technique for FRP confinement of square RC columns under eccentric loading. Journal of Compostes for Construction 2015;04015077-1-12.

[48] Yazici V, Hadi M. Axial load bending moment diagrams of Carbon FRP wrapped hollow core reinforced concrete columns. Journal of Composites for Construction 2009;13(4):262-268.

[49] Hadi M, Zhao H. Experimental study of high strength concrete columns confined with different types of mesh under eccentric and concentric loads. Journal of Materials in Civil Engineering 2011;23(6):823-832.

(1)

5

(1)


664 Test Matrix

\begin{tabular}{|c|c|c|c|c|c|}
\hline $\begin{array}{c}\text { Test } \\
\text { specimen }\end{array}$ & $\begin{array}{l}\text { Internal } \\
\text { diameter } \\
(\mathrm{mm})\end{array}$ & $\begin{array}{l}\text { Height } \\
(\mathrm{mm})\end{array}$ & $\begin{array}{c}\text { Internal } \\
\text { longitudinal } \\
\text { reinforcement }\end{array}$ & $\begin{array}{c}\text { Lateral } \\
\text { confinement }\end{array}$ & Test eccentricity \\
\hline REF-0 & 205 & 800 & Steel & Steel & 0 \\
\hline REF-25 & & & & & 25 \\
\hline REF-50 & & & & & 50 \\
\hline REF-B & & & & & Four point load \\
\hline CT-0 & 203 & 812 & - & CFRP Tube & 0 \\
\hline CT-25 & & & & & 25 \\
\hline CT-50 & & & & & 50 \\
\hline CT-B & & & & & Four point load \\
\hline GT-0 & 203 & 812 & - & GFRP Tube & 0 \\
\hline GT-25 & & & & & 25 \\
\hline GT-50 & & & & & 50 \\
\hline GT-B & & & & & Four point load \\
\hline CTCR-0 & 203 & 812 & CFRP & CFRP Tube & 0 \\
\hline CTCR-25 & & & & & 25 \\
\hline CTCR-50 & & & & & 50 \\
\hline CTCR-B & & & & & Four point load \\
\hline GTGR-0 & 203 & 812 & GFRP & GFRP Tube & 0 \\
\hline GTGR-25 & & & & & 25 \\
\hline GTGR-50 & & & & & 50 \\
\hline GTGR-B & & & & & Four point load \\
\hline
\end{tabular}

665

666

667

668

669

670

671

672

673

674

675

676 
Table 2

678 Mechanical properties of FRP tubes

\begin{tabular}{ccccc}
\hline \multirow{2}{*}{ Tube type } & $\begin{array}{c}\text { Modulus of } \\
\text { elasticity in } \\
\text { circumferential } \\
\text { direction } E_{c} \\
(\mathrm{GPa})\end{array}$ & $\begin{array}{c}\text { Ultimate tensile } \\
\text { strength in } \\
\text { circumferential } \\
\text { direction } f_{f u, c}\end{array}$ & $\begin{array}{c}\text { Modulus of } \\
\text { elasticity in } \\
\text { longitudinal } \\
\text { direction } E_{l}\end{array}$ & $\begin{array}{c}\text { Ultimate tensile } \\
\text { strength in } \\
\text { longitudinal } \\
\text { direction } f_{f u, l}\end{array}$ \\
\hline CT & 54 & 1188 & 169.2 & $(\mathrm{MPa})$ \\
GT & 18 & 810 & 5.4 & 142.6 \\
\hline
\end{tabular}

679

680

681

682

683

684

685

686

687

688

689

690

691

692

693

694

695

696

697

698 
700 Test results of specimens tested under concentric, 25 and $50 \mathrm{~mm}$ eccentric axial loads

\begin{tabular}{ccccc}
\hline $\begin{array}{c}\text { Test } \\
\text { specimen }\end{array}$ & $\begin{array}{c}\text { Peak axial } \\
\text { load (kN) }\end{array}$ & $\begin{array}{c}\text { Axial } \\
\text { deformation } \\
\text { at peak axial } \\
\text { load (mm) }\end{array}$ & $\begin{array}{c}\text { Lateral } \\
\text { deformation } \\
\text { at peak axial } \\
\text { load (mm) }\end{array}$ & Ductility $(\mu)$ \\
\hline REF-0 & 1529 & 2.4 & - & 6.7 \\
REF-25 & 888 & 4.2 & 3.3 & 5.3 \\
REF-50 & 594 & 3.2 & 3.2 & 3.7 \\
CT-0 & 1770 & 18.1 & - & 11.6 \\
CT-25 & 755 & 3.5 & 4.7 & 8.1 \\
CT-50 & 489 & 2.8 & 3.9 & 3.6 \\
GT-0 & 1884 & 21.3 & - & 14.6 \\
GT-25 & 860 & 4.2 & 5.8 & 8.4 \\
GT-50 & 523 & 4.1 & 4.0 & 4.3 \\
CTCR-0 & 2197 & 20.9 & - & 10.2 \\
CTCR-25 & 1182 & 6.5 & 12.3 & 8.2 \\
CTCR-50 & 666 & 4.3 & 19.2 & 6.4 \\
GTGR-0 & 2812 & 23.1 & - & 12.6 \\
GTGR-25 & 1487 & 13.5 & 13.4 & 9.2 \\
GTGR-50 & 910 & 11.6 & 21.0 & 7.7 \\
\hline
\end{tabular}

701

702

703

704

705

706

707

708

709

710

711

712

713 
Table 4

715 Test results of specimens tested under four point loads

\begin{tabular}{cccc}
\hline Test specimen & $\begin{array}{c}\text { Peak } \\
\text { flexural } \\
\text { load (kN) }\end{array}$ & $\begin{array}{c}\text { Midspan } \\
\text { deflection at } \\
\text { peak flexural } \\
\text { load }(\mathrm{mm})\end{array}$ & $\begin{array}{c}\text { Ductility } \\
(\mu)\end{array}$ \\
\hline REF-B & 347 & 37.3 & 9.9 \\
CT-B & 93 & 26.7 & 3.6 \\
GT-B & 116 & 27.1 & 4.9 \\
CTCR-B & 223 & 28.2 & 8.7 \\
GTGR-B & 448 & 29.1 & 9.8 \\
\hline
\end{tabular}

716

717

718

719

720

721

722

723

724

725

726

727

728

729

730

731

732

733 
Table 5

7B5x Experimental peak axial load and bending moment capacities of tested specimens

\begin{tabular}{cccc}
\hline $\begin{array}{c}\text { Test } \\
\text { specimen }\end{array}$ & $\begin{array}{c}\text { Peak axial } \\
\text { load }(\mathrm{kN})\end{array}$ & $\begin{array}{c}\text { Lateral } \\
\text { deformation at } \\
\text { peak axial load } \\
(\mathrm{mm})\end{array}$ & $\begin{array}{c}\text { Moment } \\
\text { capacity } \\
(\mathrm{kN} . \mathrm{m})\end{array}$ \\
\hline REF-0 & 1529 & - & 0.0 \\
REF-25 & 888 & 3.3 & 25.1 \\
REF-50 & 594 & 3.2 & 31.6 \\
REF-B & 347 & 37.3 & 27.0 \\
CT-0 & 1770 & - & 0.0 \\
CT-25 & 755 & 4.7 & 22.4 \\
CT-50 & 489 & 3.9 & 26.3 \\
CT-B & 93 & 26.7 & 11.0 \\
GT-0 & 1884 & - & 0.0 \\
GT-25 & 860 & 5.8 & 26.5 \\
GT-50 & 523 & 2.3 & 27.4 \\
GT-B & 116 & 27.1 & 13.8 \\
CTCR-0 & 2197 & - & 0.0 \\
CTCR-25 & 1182 & 12.3 & 44.1 \\
CTCR-50 & 666 & 19.2 & 46.1 \\
CTCR-B & 223 & 28.2 & 26.3 \\
GTGR-0 & 2812 & - & 0.0 \\
GTGR-25 & 1487 & 13.4 & 57.1 \\
GTGR-50 & 910 & 19.8 & 63.5 \\
GTGR-B & 448 & 29.1 & 52.6 \\
\hline
\end{tabular}

736

737

738

739

740

741

742

743

744

745

746

747 


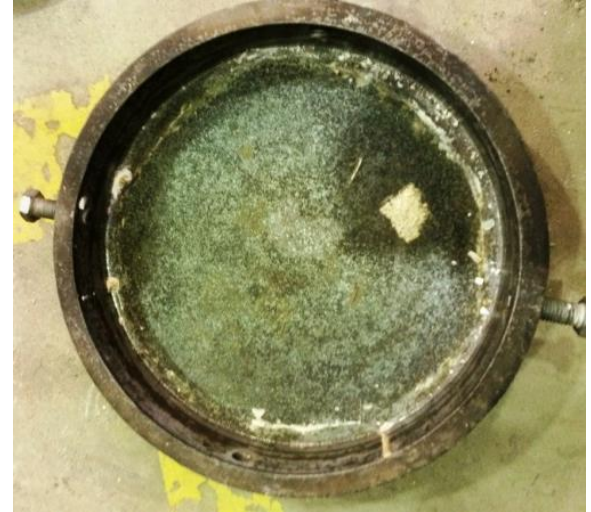

(a)

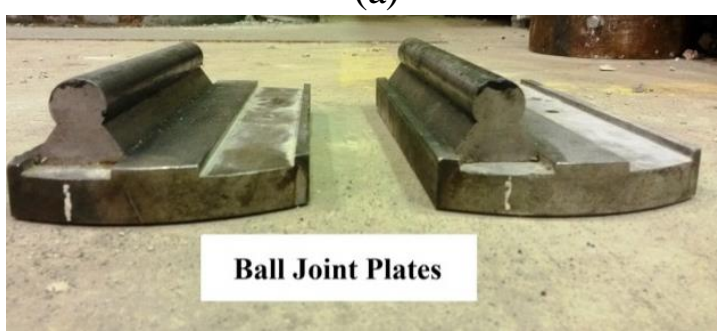

(c)

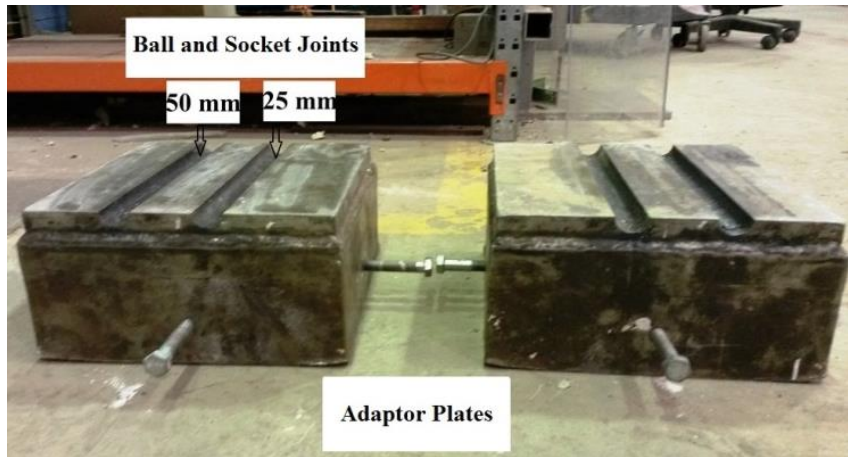

(b)

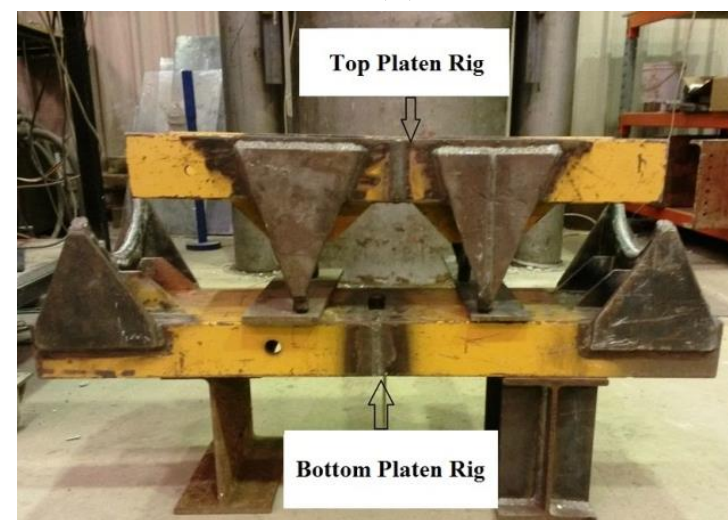

(d)

Fig. 1. Test apparatus (a) Concentric loading Heads, (b) Eccentric Adaptor Plates, (c) 


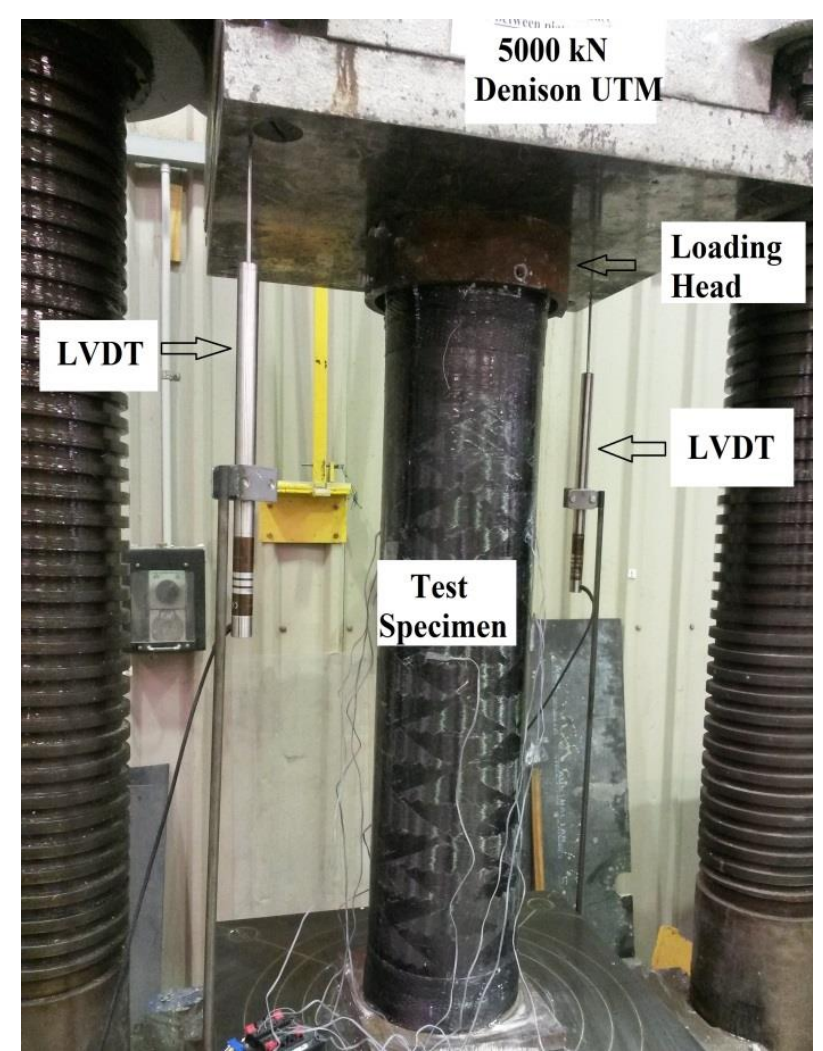

(a) Concentric

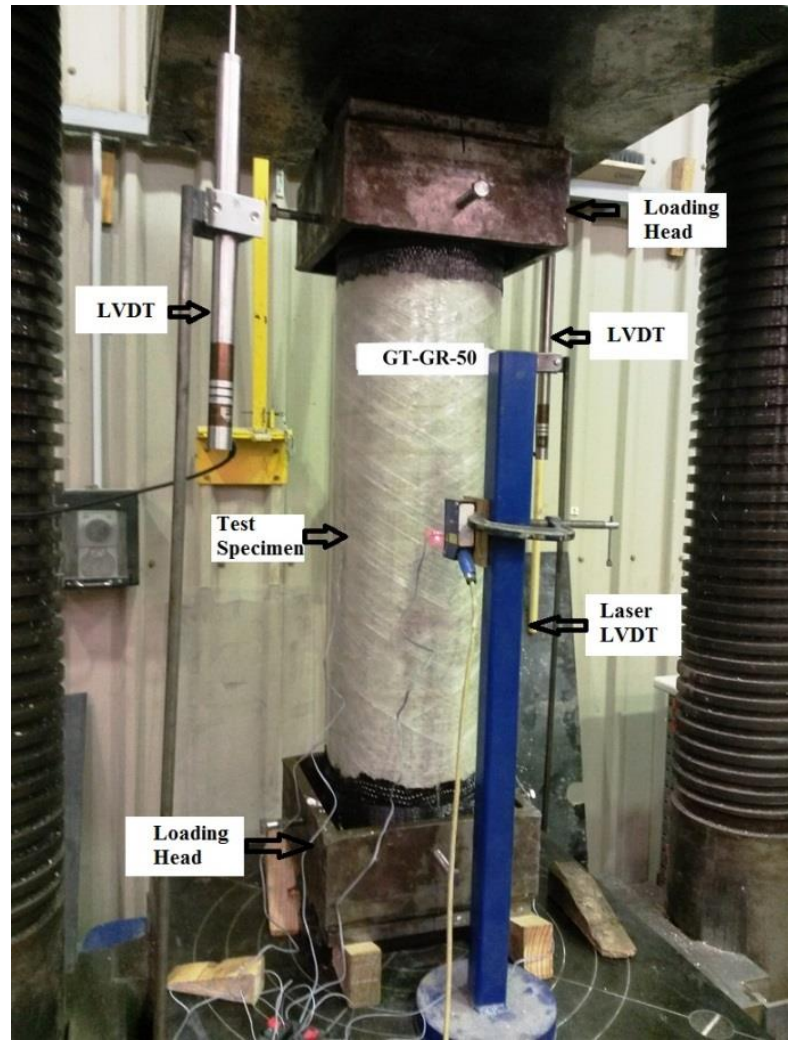

(b) Eccentric

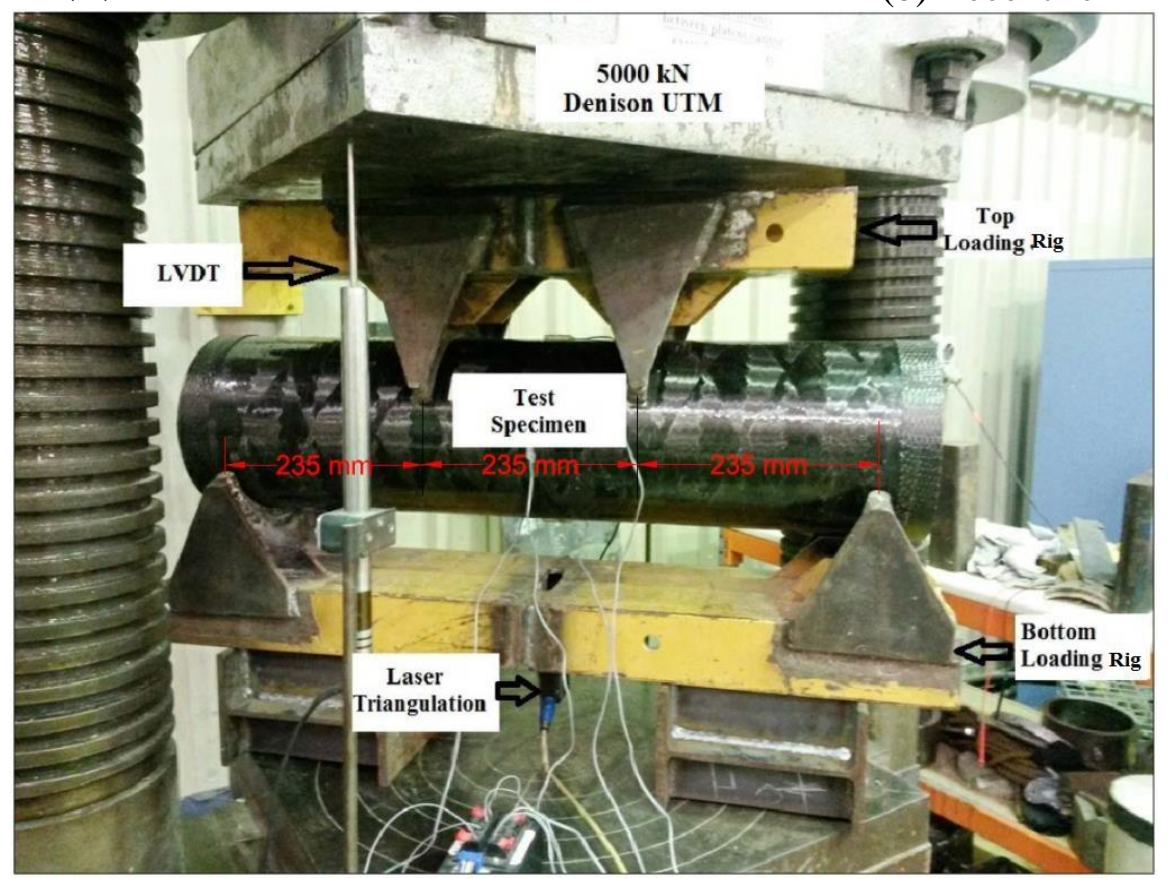

(c) Four point loads

752 


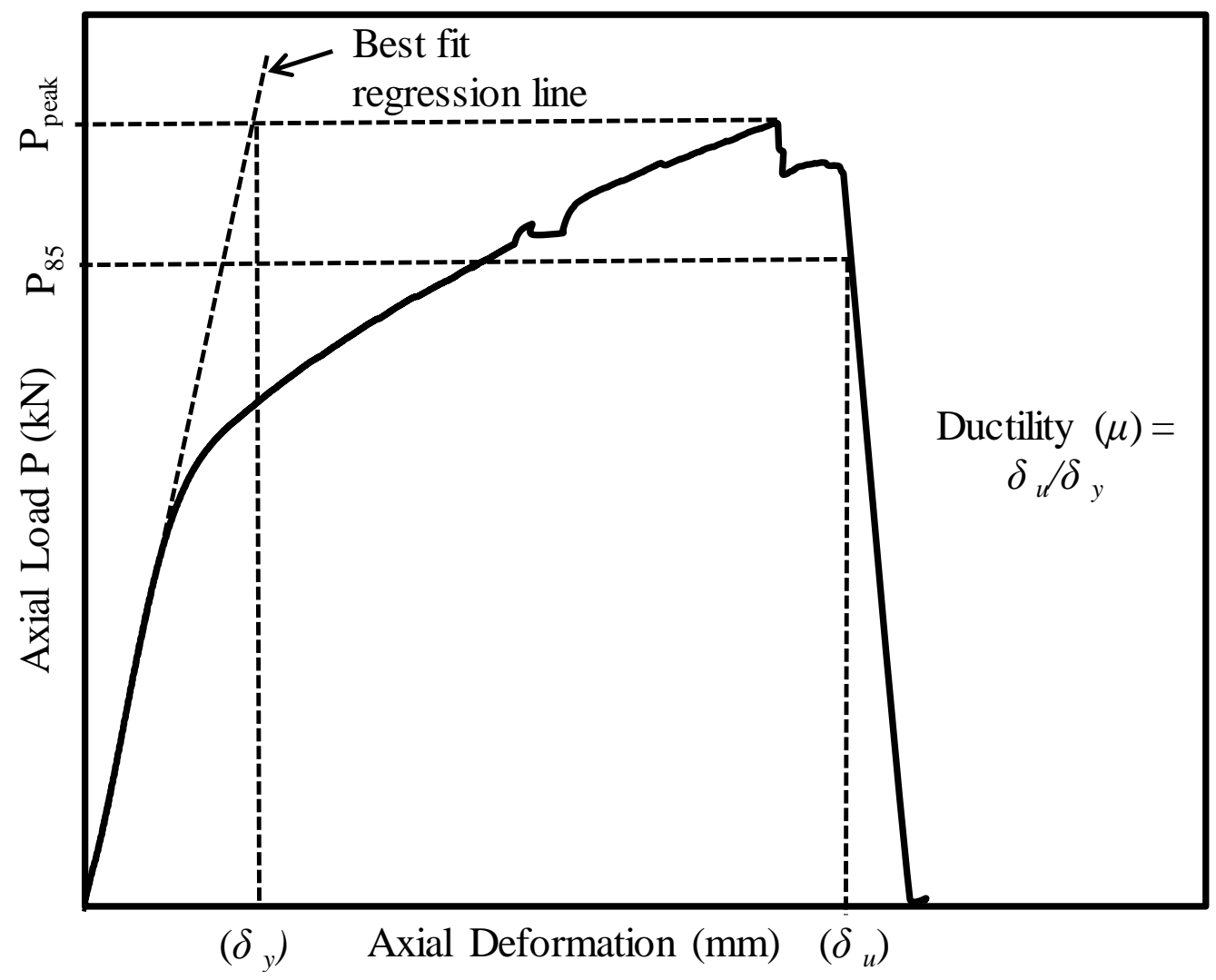

Fig. 3. Calculation of ductility of tested specimens

758

759

760 


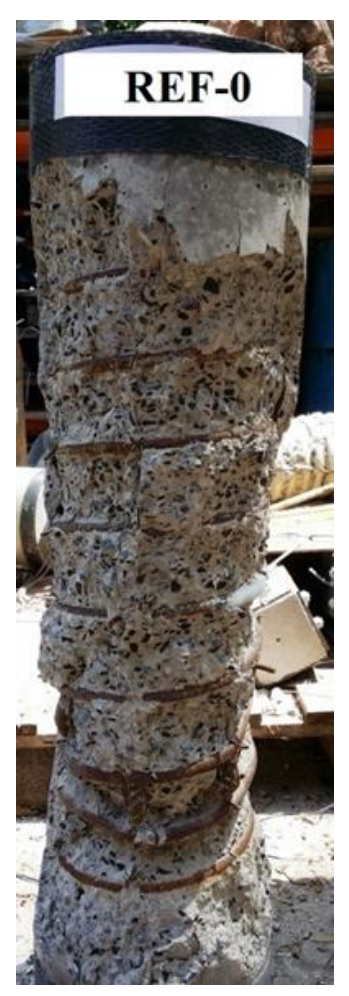

761

762

763

764

765

766

767

768

769

770

771

772

773

774

775
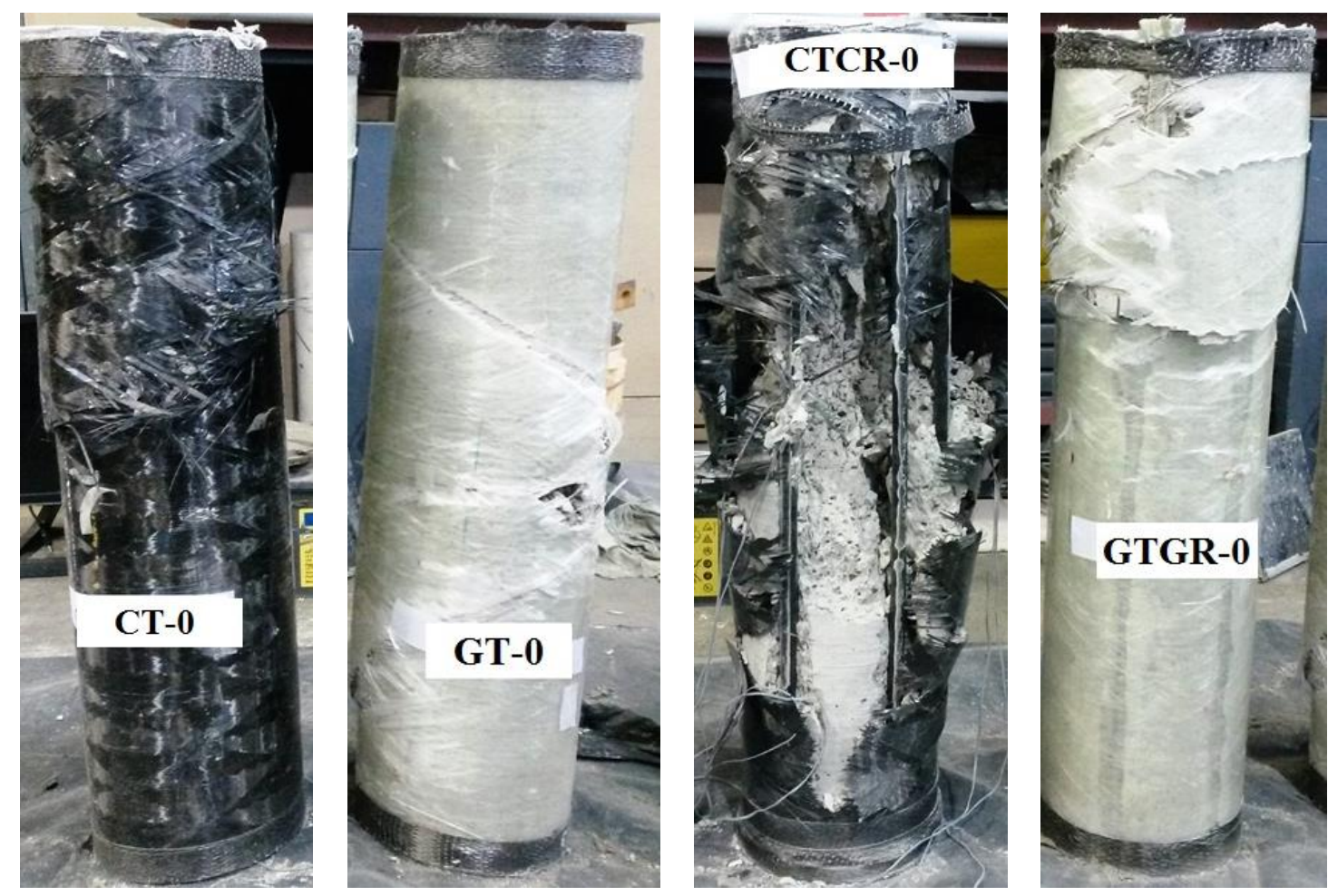

Fig. 4. Specimens tested under concentric axial load 


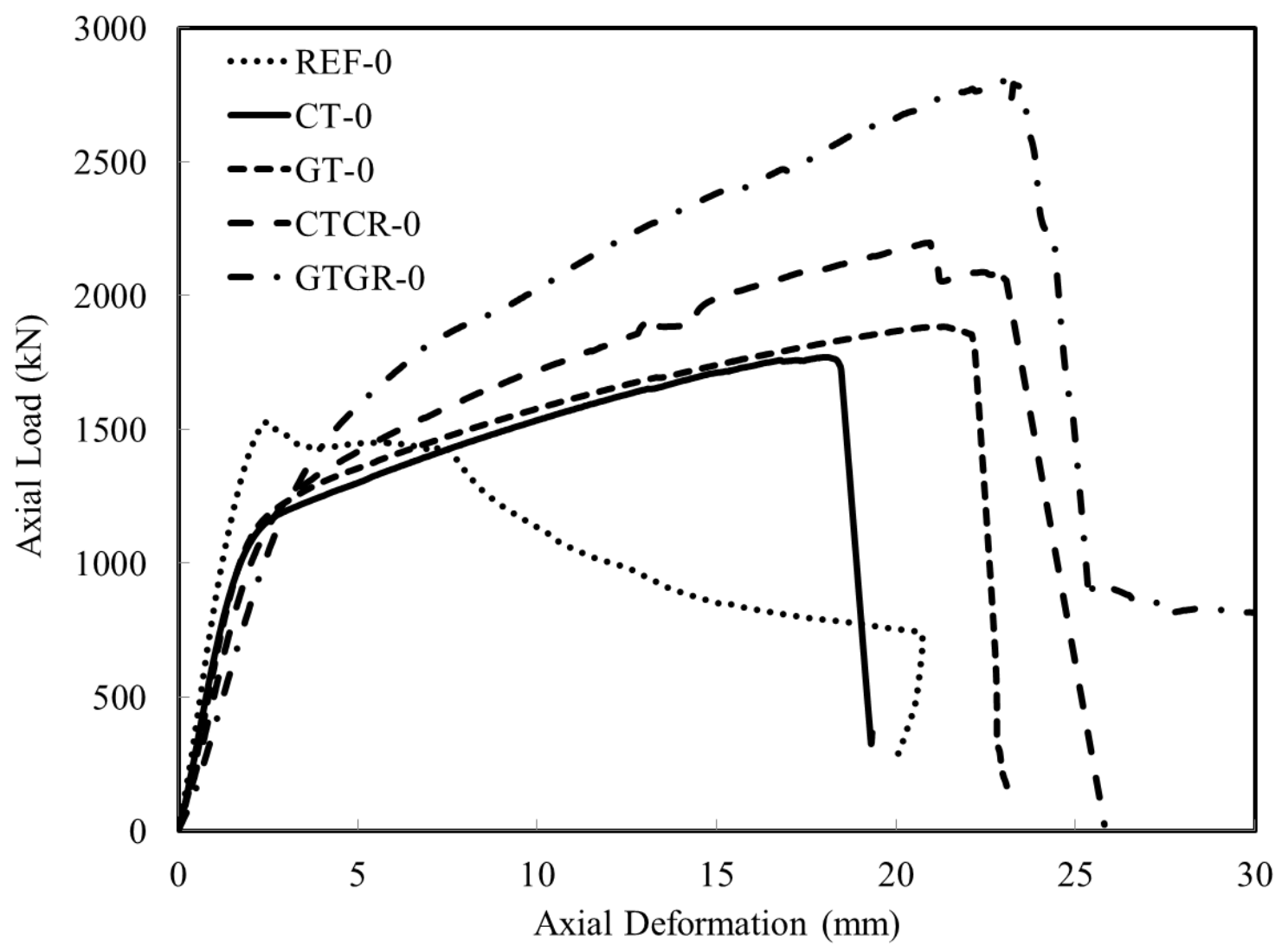

777 Fig. 5. Axial load-axial deformation behavior of specimens tested under concentric axial load 778 


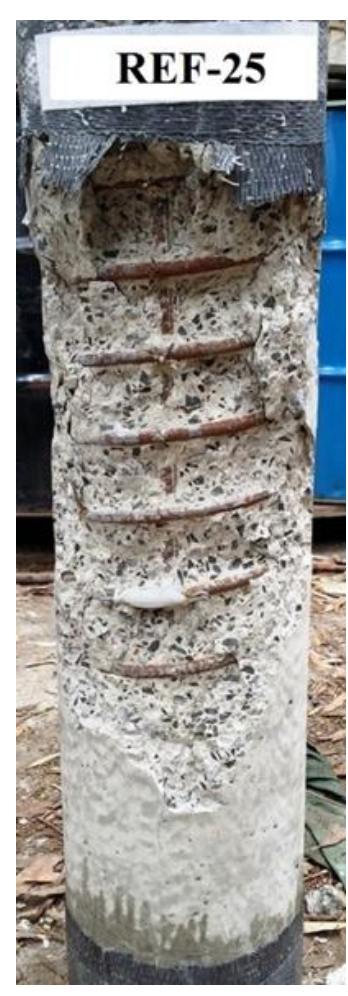

781

782

783

784

785

786

787

788

789

790

791

792

793

794

795
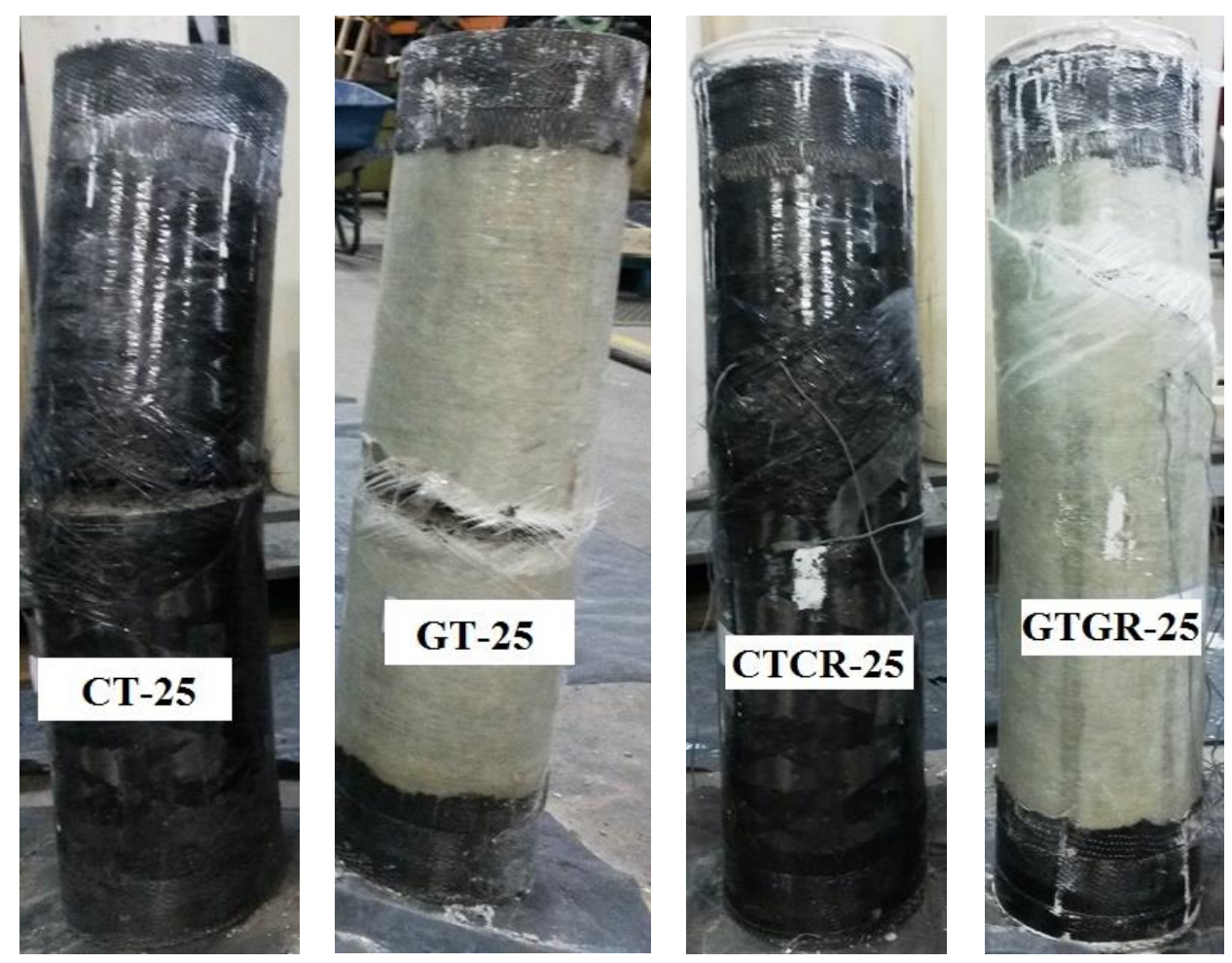

Fig. 6. Specimens tested under $25 \mathrm{~mm}$ eccentric axial load 


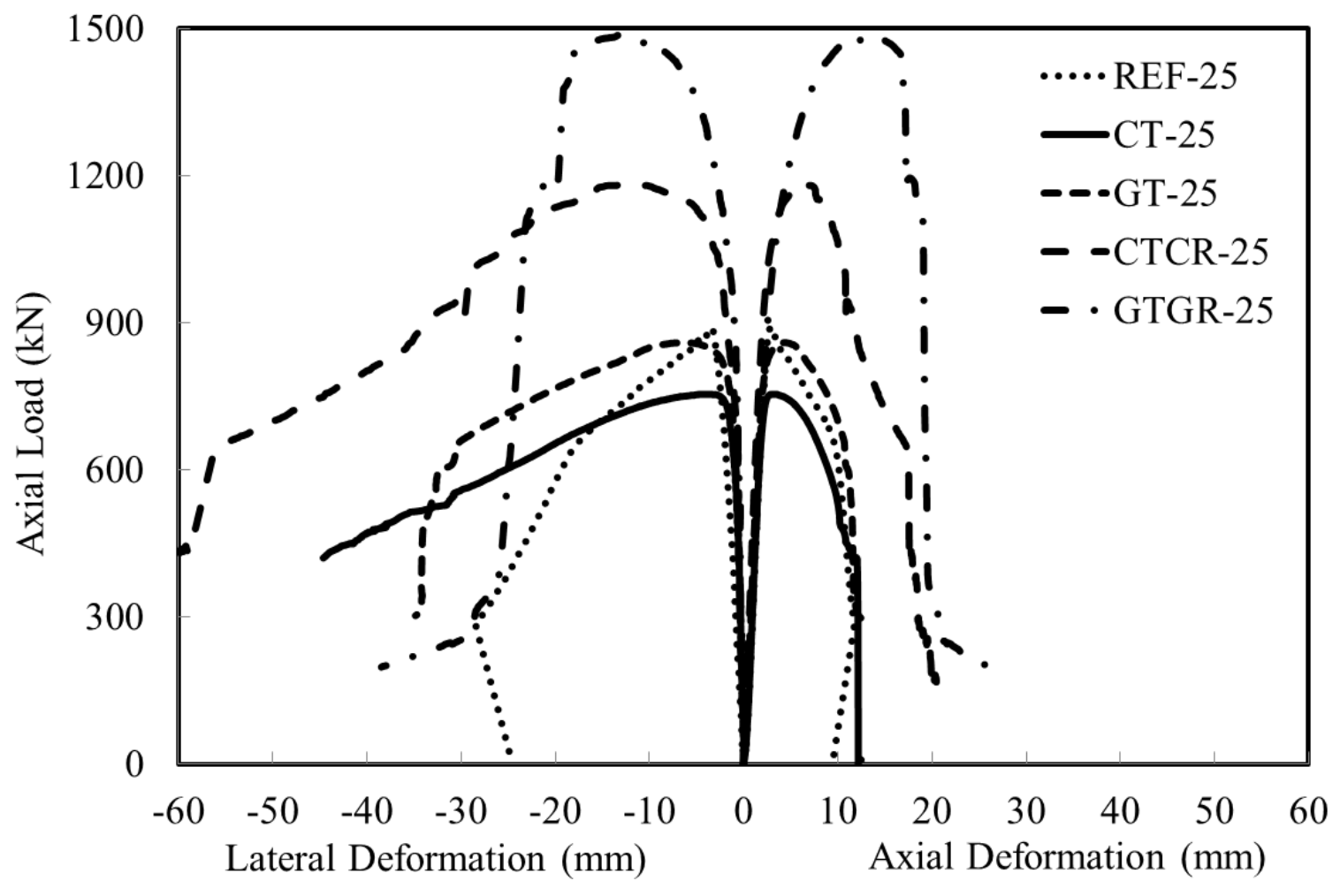

797

Fig. 7. Axial load-axial deformation and axial load-lateral deformation behavior of specimens tested under $25 \mathrm{~mm}$ eccentric axial load

799

800

801 


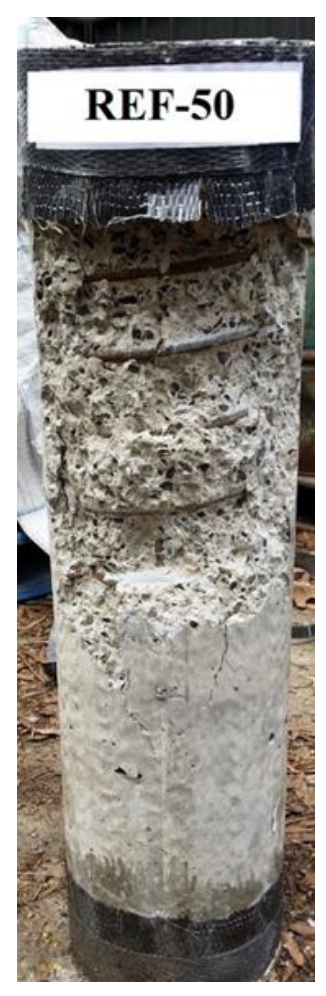

802

803

804

805

806

807

808

809

810

811

812

813

814

815

816

3

.
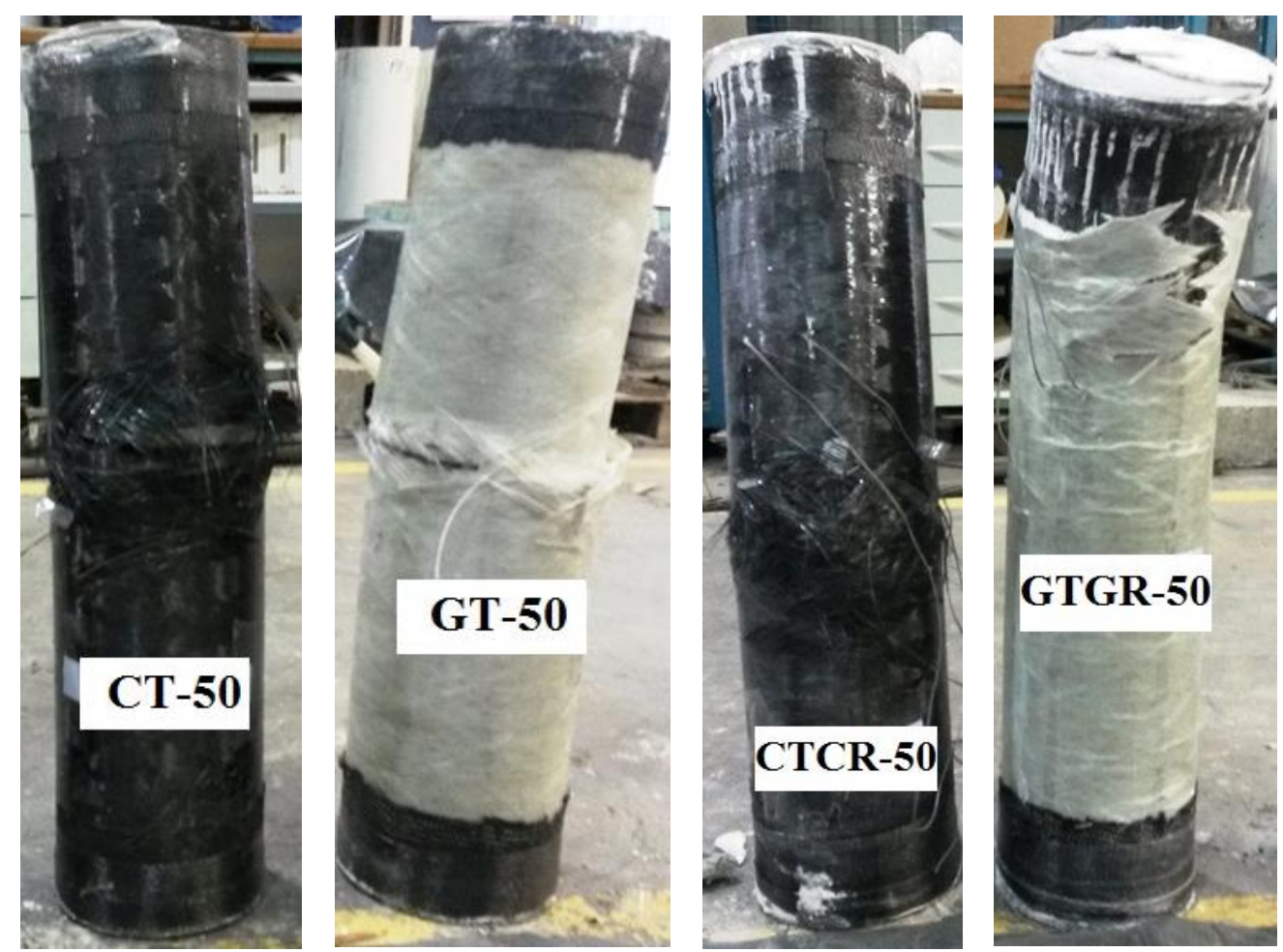

Fig. 8. Specimens tested under $50 \mathrm{~mm}$ eccentric axial load 


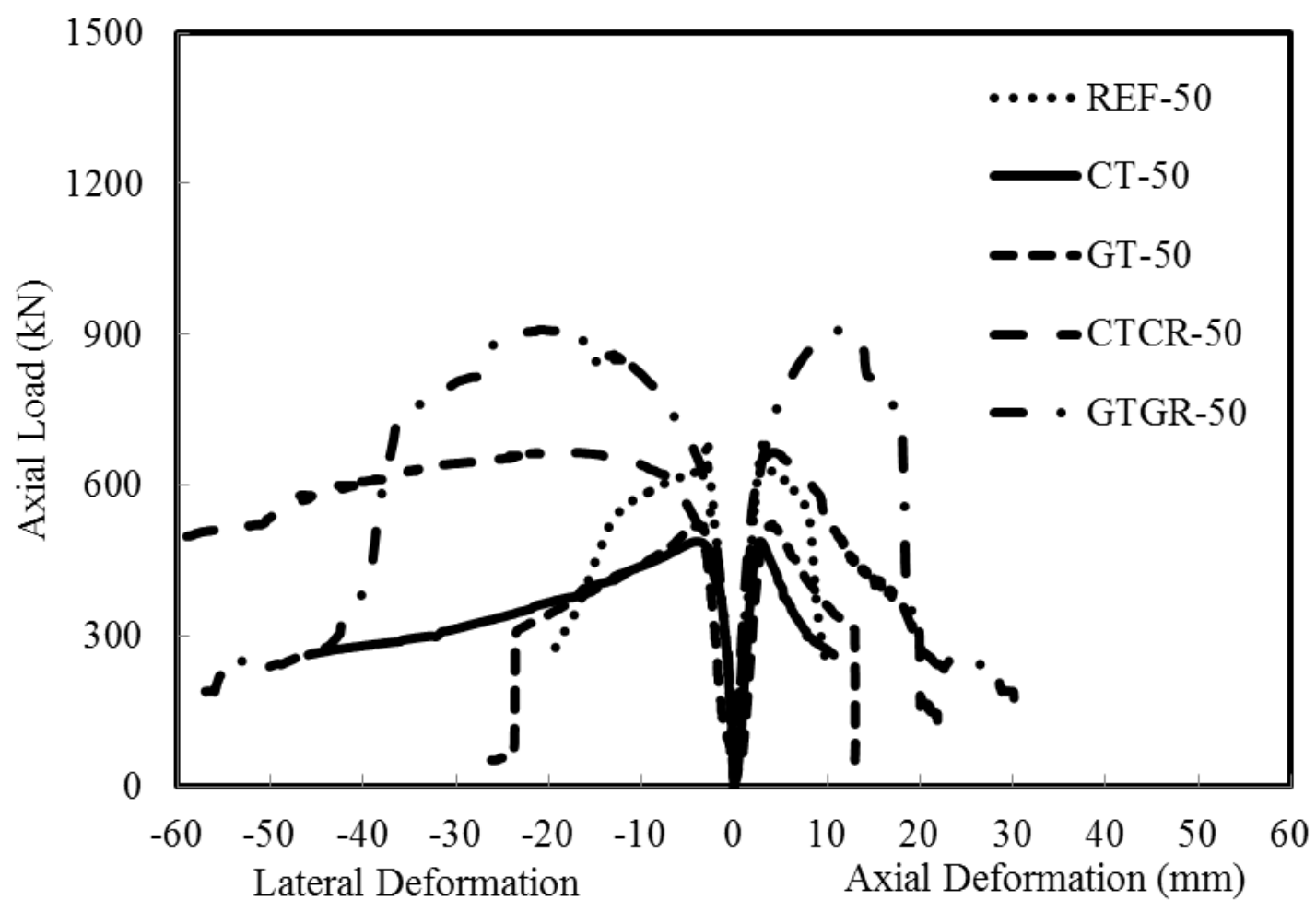

Fig. 9. Axial load-axial deformation and axial load-lateral deformation behavior of specimens 


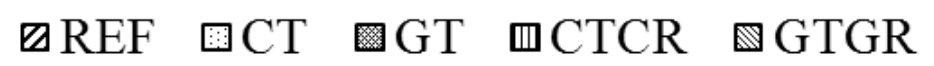

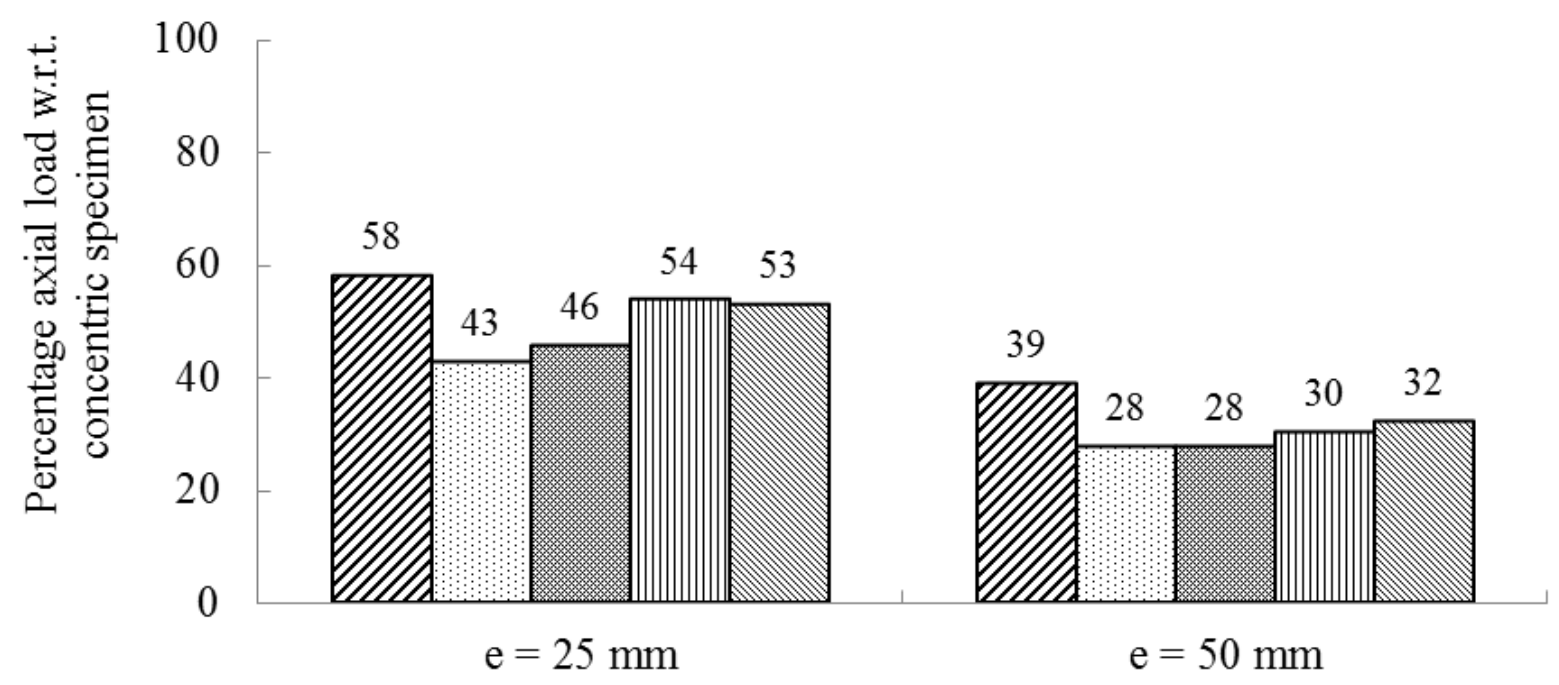

(a) Peak axial load

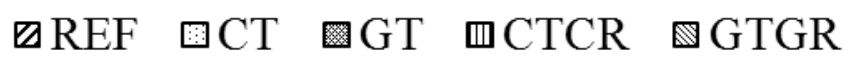

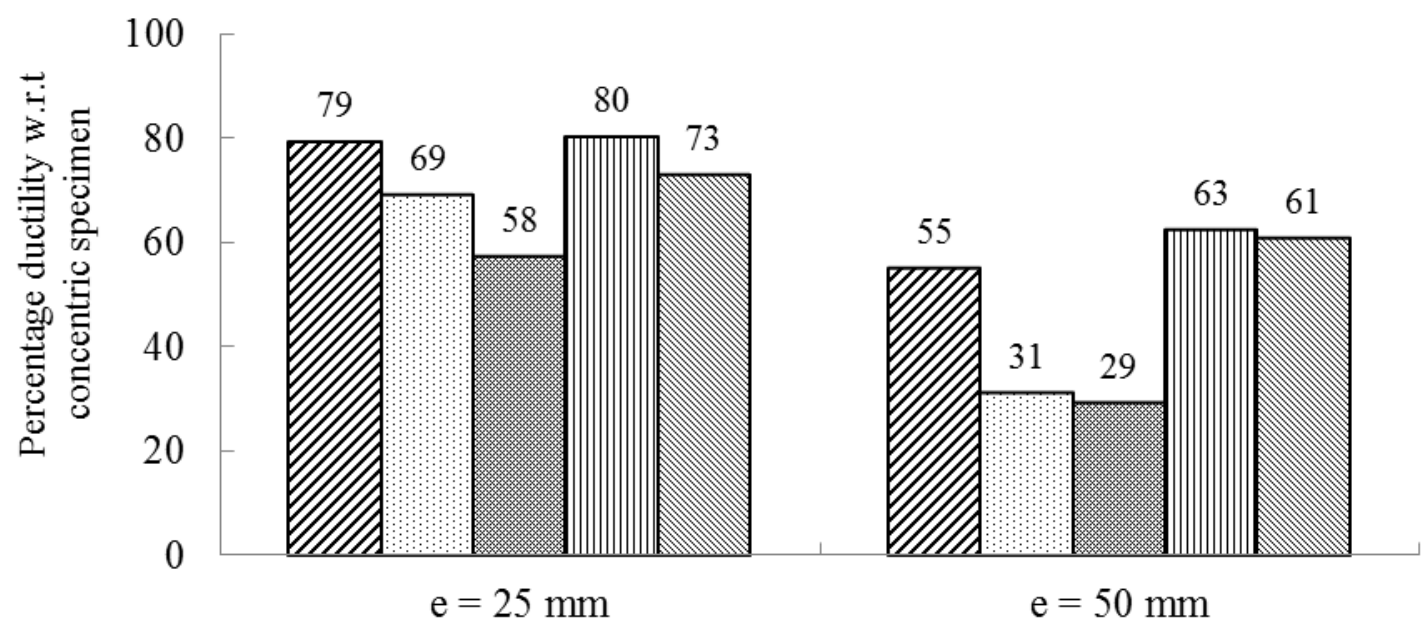

(b) Ductility

Fig. 10. Effect of eccentricity (a) Peak axial load and (b) Ductility 

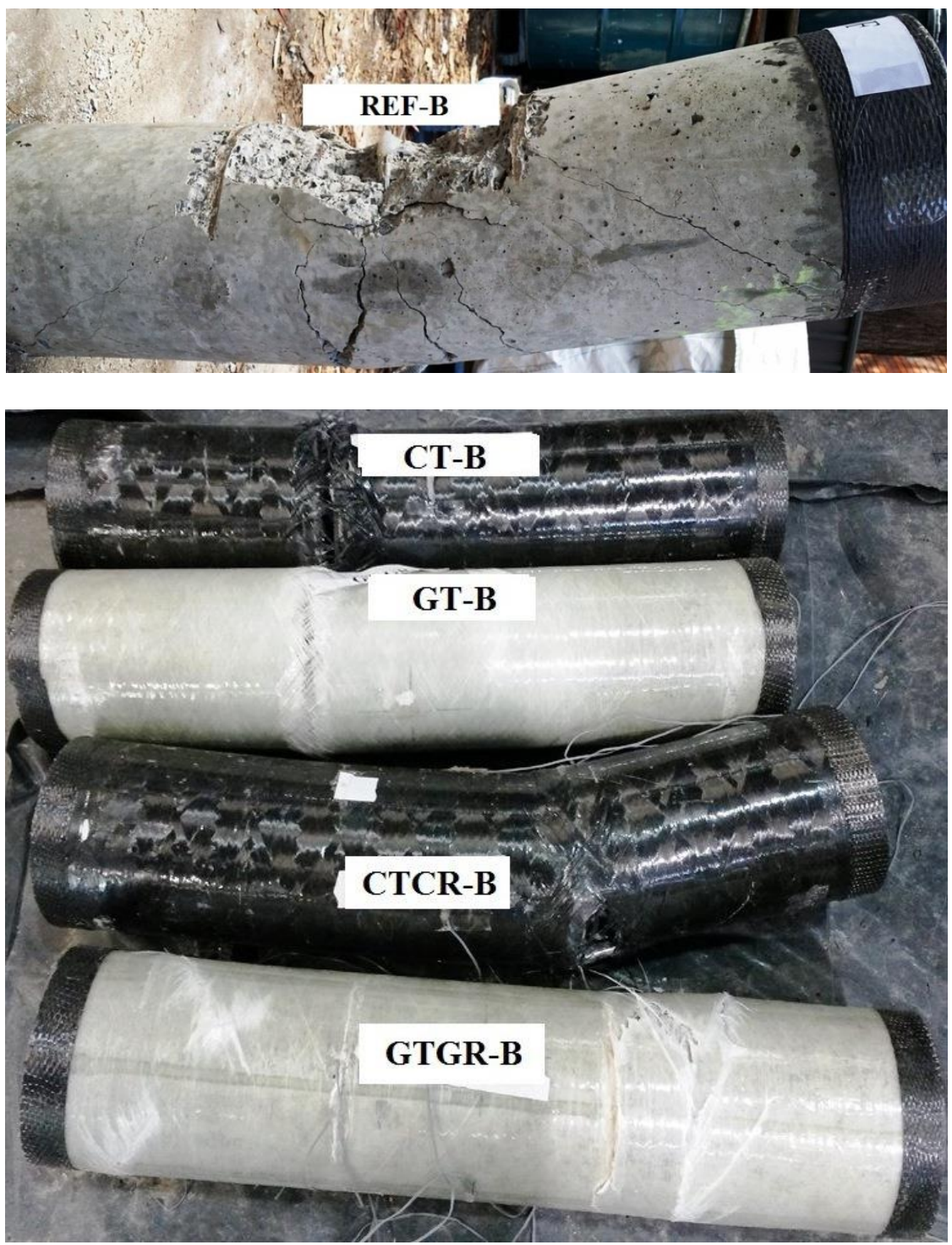

Fig. 11. Specimens tested under four point loads

836

837

838

839

840

841

842 


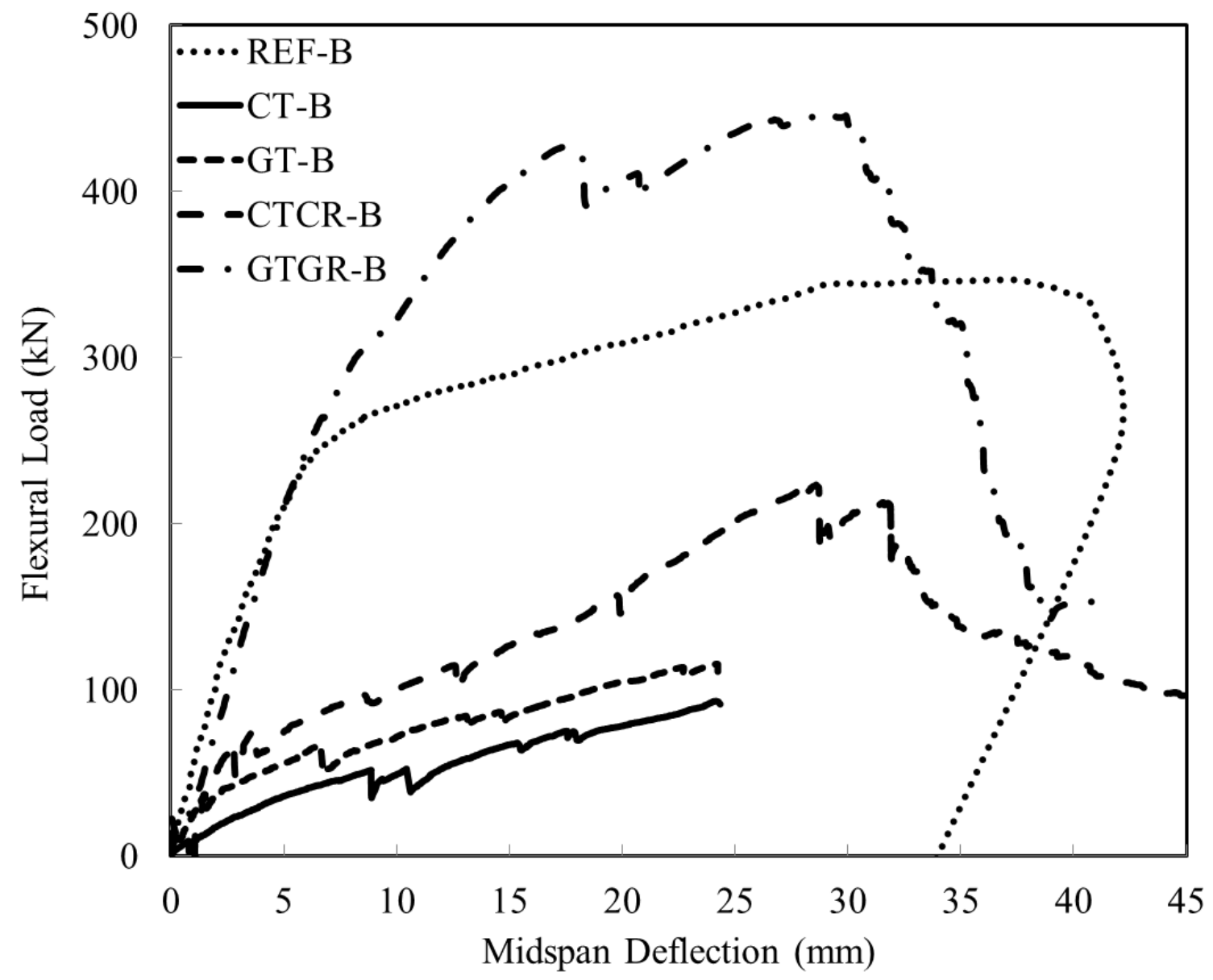

843 Fig. 12. Flexural load-midspan deflection behavior of specimens tested under four point loads 844 


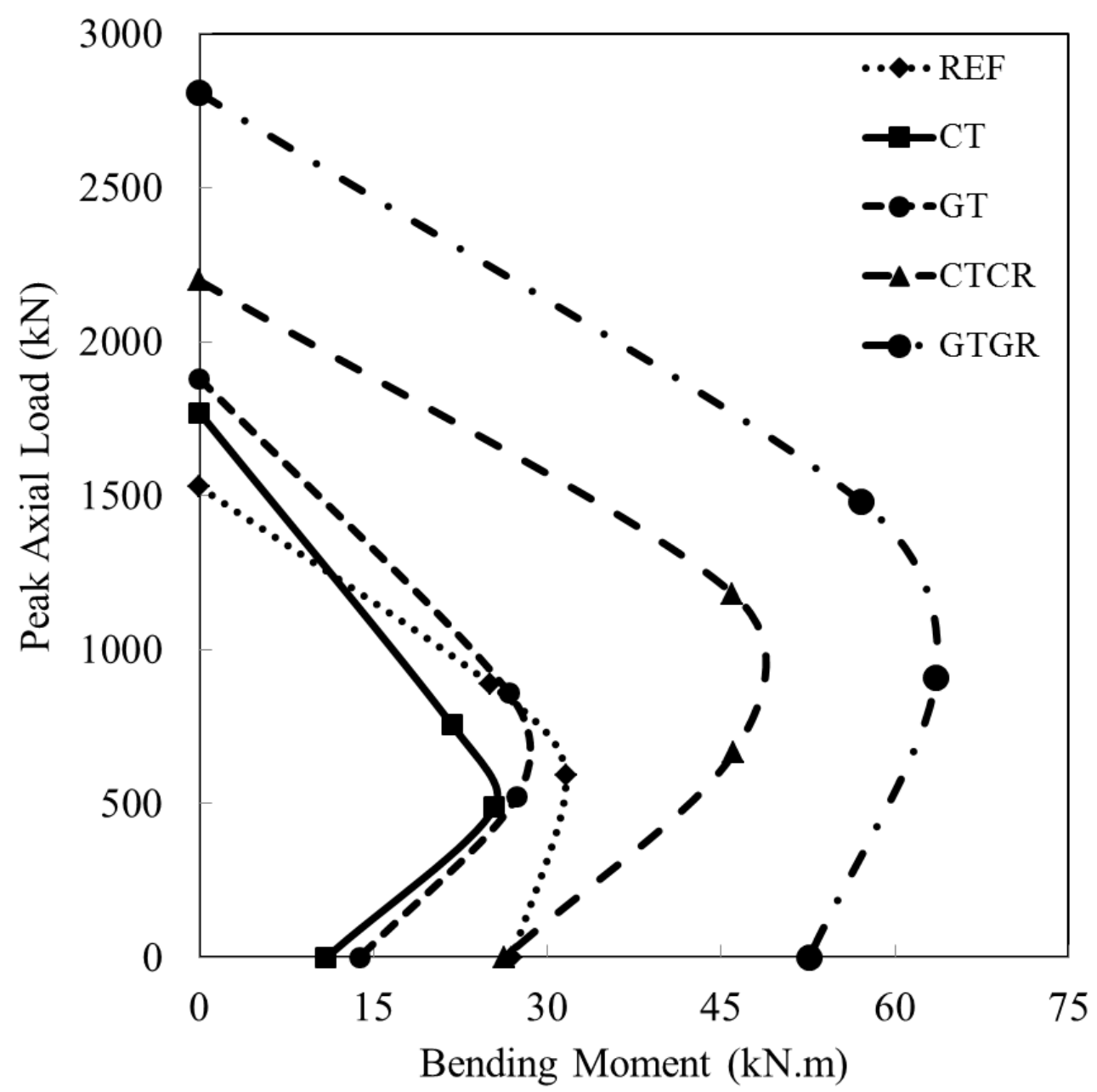

Fig. 13. Peak axial load bending moment interaction diagram of REF, CT, GT, CTCR and GTGR specimens 